\title{
LIETUVOS KARIUOMENĖS KAMPANIJA 1712 M. IR PROŠVEDIŠKO PERVERSMO GALIMYBĖS LIETUVOS DIDŽIOJOJE KUNIGAIKŠTYSTĖJE
}

\author{
Dr. Mindaugas Šapoka \\ Lietuvos istorijos institutas
}

\begin{abstract}
Anotacija. Šis straipsnis skirtas iki šiol istoriografijoje menkai tyrinètai paskutiniajai Didžiojo Šiaurès karo (1700-1721 m.) 1712-ujų metu karinei kampanijai, kuri vyko Lietuvos Didžiosios Kunigaikštystès teritorijoje ir kurioje dalyvavo Lietuvos kariuomene, aptarti.
\end{abstract}

Pagrindiniai žodžiai: Didysis Šiaurès karas, Abieju Tautu Respublika, Osmanu imperija, Švedija, Karolis XII, Augustas II, Stanislovas Leščinskis, Liudvikas Pociejus, Jonas Kazimieras Sapiega, Jonas Grudzinskis, Lietuvos kariuomene, Lenkijos kariuomene, Rusijos kariuomene

\section{IVADAS}

Šis straipsnis skirtas paskutinei Didžiojo Šiaurès karo (1700-1721 m. $)^{1}$ karinei kampanijai, vykusiai ir Lietuvos teritorijoje, kurioje aktyviai dalyvavo Lietuvos Didžiosios Kunigaikštystès kariuomenè, aptarti.

Didysis Šiaurès karas iki Poltavos mūšio 1709 m. vyko beveik išskirtinai Lenkijos ir Lietuvos valstybès, dar vadinamos Abiejų Tautų Respublika (toliau - Respublika), teritorijoje. Švedijos kariuomenei pralaimejjus Poltavos mūši, intensyvūs karo veiksmai joje nebevyko, bet krašte buvo gausu Švedijos karalių Karolị XII ir jo statytinị marionetinị Lenkijos ir Lietuvos valdovą Stanislovą Leščinskị (1704-1709) palaikančių šalininkų (šiame straipsnyje vadinamų partizanais), kurie organizavo partizaninio karo veiksmus prieš Lenkijos, Lietuvos, Saksonijos ir Rusijos ka-

1 Lietuviškojoje istoriografijoje dar vartojamas terminas „Šiaurès karas“. 
riuomenes. Partizanai ị Lenkijos teritoriją dažnai įsiverždavo iš Osmanų imperijos valdų ir jai priklausančių teritorijų, o Lietuvą jie puldinèjo iš vadinamosios Kunigaikštiškosios Prūsijos, priklausančios Brandenburgui-Prūsijai². 1712 m. karinès kampanijos metu Lenkijos ir Lietuvos kariuomenès, padedant Rusijos kariuomenei, iš esmès sutriuškino ir išblaškè didesnes švedus palaikančių partizanų grupuotes. Pasibaigus $1712 \mathrm{~m}$. karinei kampanijai, jos daugiau nebekèlè politinès ir karinès grèsmès Respublikos valdovo Augusto II valdžiai. Nesèkminga $1712 \mathrm{~m}$. kampanija lèmé tai, kad daugelis partizanų vadų pasitrauke iš Brandenburgo-Prūsijos $\mathfrak{i}$ Benderų miestą dabartinès Moldavijos teritorijoje, kur gavęs laikiną turkų prieglobstị po Poltavos mūšio gyveno Švedijos karalius Karolis XII.

\section{LITERATŪROS APŽVALGA}

1712 m. karinè kampanija Respublikos teritorijoje jau yra sulaukusi istorikų dèmesio. Pirmiausia reikètų paminèti Kazimiero Jarochovskio (Kazimierz Jarochowski) ir Mareko Vagnerio (Marek Wagner) straipsnius $^{3}$. Jų tyrimo objektas buvo Švedijos karaliaus Karolio XII ir Stanislovo Leščinskio šalininko Jono Grudzinskio (Jan Grudziński) kavalerijos dalinių reidas ị Lenkijos karalystès teritoriją $1712 \mathrm{~m}$. vasarą iš Osmanų imperijai pavaldžios Moldavijos kunigaikštystès. Karo veiksmai Lietuvos Didžiosios Kunigaikštystės teritorijoje $1712 \mathrm{~m}$. šių istorikų darbuose liko nuošalyje. Istorikai neišvengè klaidų ir netikslumų. M. Vagneris rašè, kad Bobruisko seniūno ir Lietuvos didžiojo etmono, paskirto ị šias pareigas, Stanislovo Leščinskio Jono Kazimiero Sapiegos (Jan Kazimierz Sapieha) žygiui buvo rengiamasi Benderuose. Per Podolę jis neva turējo pasiekti Lietuvos žemes ir pakurstyti Lietuvos bajoriją pradèti sukilimą prieš Au-

\footnotetext{
2 Nors formaliai Brandenburgas-Prūsija tapo karalyste 1701 m., Respublika Frydricho I karūnavimo nepripažino, todèl straipsnyje vartojamas terminas „Kunigaikštiškoji Prūsija“. 3 Jarochowski K. Wycieczka Grudzińśkiego, starosty Rawskiego, do Polski w roku 1712. Opowiadania i studia historyczne, t. 2, Poznań, 1863, s. 317-385; Wagner M. Zagon Kawaleryjski Jana Grudzińskiego w 1712 roku. Wojny pólnocne w XVI-XVIII wieku, red. B. Dybaś, Toruń, 2007, s. 209-223.
} 
gustą II. Paminima, kad šis J. K. Sapiegos planas baigèsi nesėkme ${ }^{4}$. Visgi vèliau lenkų istorikas rašo, kad pralaimejjęs mūši Didžiojoje Lenkijoje J. Grudzinskis nesèkmingai bandè susijungti su J. K. Sapiegos daliniais ${ }^{5}$. Kaip ir iš kur J. K. Sapiega atsirado netoli J. Grudzinskio, nepaaiškinta. K. Jarochovskis rašè, kad J. K. Sapiega pats asmeniškai prisijungè prie J. Grudzinskio dalinių, o vèliau, birželio viduryje, J. Grudzinskio įsakymu atsiskyrè ir išvyko ị Lietuvą, kad sukeltų maištą jos kariuomenejje ${ }^{6}$. Netikslios ir kitos K. Jarochovskio apie J. K. Sapiegos dalinių žygi pateiktos žinios. Istorikas rèmèsi Danijos archyve rastu pranešimu iš karo veiksmų zonos, kuris, labai tiketina, buvo netikslus ${ }^{7}$. Kitas lenkų istorikas Janas Vimeris (Jan Wimmer), tyręs Lenkijos ir Lietuvos kariuomenes Didžiojo Šiaurès karo laikotarpiu, $1712 \mathrm{~m}$. kampanijai skyrè keletą puslapių, tačiau rèmèsi daugiausia jau minèto K. Jarochovskio tyrimais. Neaišku, kodèl J. Vimeris J. K. Sapiegos pajègas $1712 \mathrm{~m}$. pradžioje sutelkè Podoleje. Istoriko parengtoje kampanijos schemoje taip pat yra netikslumų ${ }^{8}$.

Lietuviškosios istoriografijos žinios apie $1712 \mathrm{~m}$. karo veiksmus, kaip ir apie visą Didijj Šiaurès karą, labai fragmentiškos. Galima paminèti tik Valdą Rakutị, kuris savo straipsnyje, skirtame Liudvikui Pociejui, užsimena, kad 1712 m. vasarą L. Pociejui pavyko išstumti J. K. Sapiegos dalinius iš Lietuvos ị Sileziją .

Šiame straipsnyje naudojami Lietuvos didžiojo etmono Liudviko Pociejaus (Ludwik Pociej), žmogaus, kuris asmeniškai vadovavo Lietuvos kariuomenès operacijai prieš J. K. Sapiegos dalinius, laiškai atskleidžia

4 Wagner M. Zagon Kawaleryjski Jana Grudzińskiego w 1712 roku, s. 214; M. Vagneris remiasi Juzefu Andžejumi Gierovskiu (Józef Andrzej Gierowski), tačiau šis lenkų istorikas teigè visiškai priešingai, t. y. kad J. K. Sapiega buvo Lietuvoje, o ne Podolèje. Žr.: Gierowski J. A. Między saskim absolutyzmem a złota wolnością. Z dziejów wewnętrznych Rzeczypospolitej w latach 1712-1715. Wrocław, 1953, s. 134-135.

5 Wagner M. Zagon Kawaleryjski Jana Grudzińskiego w 1712 roku, s. 221-223.

6 Jarochowski K. Wycieczka Grudzińśkiego, starosty Rawskiego, do Polski w roku 1712, s. $370,377$.

7 Ibid, s. 380-381.

8 Wimmer J. Wojsko Rzeczypospolitej $w$ dobie wojny północnej (1700-1717). Warszawa, 1956, s. 393-396.

9 Rakutis V. Liudvikas Konstantinas Pociejus (1709-1730). Lietuvos krašto apsaugos ministrai ir kariuomenés vadai, I tomas, LDK didieji etmonai ir sukilimu vadai. Vilnius-Kaunas, 2008, p. 208. 
tikraji karinès kampanijos vaizdą, leidžia ištaisyti iki šiol istoriografijoje buvusius netikslumus ir parodo karinių veiksmų Lietuvos teritorijoje mastą.

\section{PROŠVEDIŠKOS STOVYKLOS IRIMAS LENKIJOJE IR LIETUVOJE 1709-1711 M.}

Didysis Šiaurès karas, kurio nemažai kovos veiksmų vyko Lietuvos ir Lenkijos teritorijose, turèjo didelę itaką Lietuvos ekonominiam, socialiniam ir politiniam gyvenimui. Tai buvo epochinès reikšmès susidūrimas, kuris atskleidè jègų persiskirstymą šiaurès rytų Europoje, o pavieniai jo i̇vykiai turẻjo didelę trumpalaikę reikšmę. Vienas ryškiausių tokiu įvykių pavyzdžių - $1709 \mathrm{~m}$. liepos $8 \mathrm{~d}$. ìvykęs Poltavos mūšis, kuris, nors ir nenulèmè karo pabaigos (iki to dar buvo likę 12 metų), bet iš pagrindų pakeite politinę padètị Respublikoje.

Poltavos mūšyje sutriuškintos Švedijos kariuomenès likučiai pasidave Rusijos kariuomenei, o Švedijos karalius Karolis XII turëjo prašyti prieglobsčio Osmanų imperijoje. Su savo negausiais šalininkais, keliais šimtais švedų karių ir karininkų, šiek tiek kazokų ir lenkų, jis buvo ịkurdintas Benderų mieste, Moldavijos kunigaikštystès teritorijoje, pavaldžioje Osmanų imperijai. Nèra istorinių duomenų, kurie rodytų, kad Karolio XII aplinkoje buvo lietuvių. Švedijos karaliaus artimiausioje aplinkoje buvo vos keli asmenys iš Lenkijos: Kijevo vaivada ir Lenkijos didysis etmonas, paskirtas Stanislovo Leščinskio, Juzefas Potockis (Józef Potocki), Lenkijos rūmų maršalka, taip pat paskirtas ị pareigas Stanislovo Leščinskio, Stanislovas Tarlo (Stanistaw Tarto), svarbesnių pareigų netureję Stanislovas Poniatovskis (Stanisław Poniatowski), J. Grudzinskis ir keletas kitų. $1709 \mathrm{~m}$. rugsẻji Stanislovas Leščinskis kartu su švedų kariuomenès daliniais, kurie buvo likę Respublikos teritorijoje ir nedalyvavo Poltavos mūšyje, pasitrauke link Ščecino (Stettin), kuris tuo metu priklausė Švedijai. Stanislovas Leščinskis Švedijos Pamaryje išbuvo iki pat $1712 \mathrm{~m}$. pabaigos $^{10}$.

Jau 1709 m. rugpjūčio pradžioje Rusijos kariuomenès daliniai ižengè i

10 Jarochowski K. Wycieczka Grudzińśkiego, starosty Rawskiego, do Polski w roku 1712, s. 319; Forycki M. Stanisław Leszczyński. Poznań, 2016, s. 61 
Lietuvos teritoriją. Švedų šalininkams lojalūs daliniai traukèsi Rusijos kariuomenei iš kelio. Jos žygio tikslas buvo Rygos miestas. Rusijos kariuomenè per Lietuvą žygiavo be didesnių mūšių - Lietuvos didžiojo etmono, paskirto ì pareigas Stanislovo Leščinskio, J. K. Sapiegos daliniai traukèsi link Kunigaikštiškosios Prūsijos sienos. Vyko tik pavieniai susiremimai. Turbūt didžiausias iš jų îvyko prie Slucko ${ }^{11}$. Didesnioji dalis J. K. Sapiegai pavaldžios kariuomenès nesipriešino ir $1709 \mathrm{~m}$. lapkričio mèn. perèjo naujojo Lietuvos didžiojo etmono L. Pociejaus žinion.

1706 m. atsisakęs Respublikos sosto, Augustas II grįžo ị šalị su Saksonijos kariuomene. Oficialiai jo grižimą patvirtino $1709 \mathrm{~m}$. Torunès ir 1710 m. Varšuvos konfederacinès tarybos. Jègų persvara buvo Rusijos ir Augusto II šalininkų pusejje, todèl absoliuti dauguma Švedijos ir Stanislovo Leščinskio šalininkų Lietuvos Didžiosios Kunigaikštystės pareigūnų skubejjo palikti Stanislovo Leščinskio stovyklą ir užsitikrinti Rusijos caro Petro I amnestiją. Lietuvos kancleriui Karoliui Stanislovui Radvilai ( $\mathrm{Ka}$ rol Stanisław Radziwiłt) tai pavyko padaryti lengviausiai, pakancleriui Stanislovui Ščiukai (Stanisław Szczuka) - kiek sunkiau, o abiem Lietuvos etmonams, paskirtiems Stanislovo Leščinskio, - didžiajam etmonui Jonui Kazimierui Sapiegai ir lauko etmonui Mykolui Servacijui Višnioveckiui (Michał Serwacy Wiśniowiecki) - skirtingai. Pastarasis buvo suimtas Rusijos kariuomenès dalinių ir tik po poros metų ištrūko iš nelaisvès.

Nors J. K. Sapiega formaliai susitaikè su Augustu II ir Petru I, bet tai jis padarè tik noredamas išlaikyti didžiojo etmono urèdą, o jeigu to nepavyktų padaryti, tikèjosi gauti lauko etmono pareigybę, ypač po M. S. Višnioveckio suėmimo ir Lietuvos etmono, paskirto Augusto II, Grigaliaus Oginskio (Grzegorz Ogiński) mirties. Neigiamas caro požiūris i visą Sapiegu giminę, kaip ì kolaborantus su švedais, ir tai, kad J. K. Sapiega neturèjo ką pasiūlyti nei carui, nei Augustui II, lèmé, kad jis liko be nieko: Lietuvos etmonų urẻdai buvo atiduoti ištikimiems Augusto II ir karinès sąjungos su Rusija šalininkams. Liudvikas Pociejus tapo didžiuoju etmonu, o lauko etmono buožę gavo Augustą II remiančios Sandomiro konfederacijos maršalka Stanislovas Denhofas (Stanisław Denhoff). Šis Augusto II ir Petro I sprendimas izžeidè J. K. Sapiegos ambicijas. Jų

11 Jonas Mikalojus Radvila (Jan Mikołaj Radziwiłt) Karoliui Stanislovui Radvilai (Karol Stanisław Radziwiłł), 1709 m. rugpjūčio 27 d., Archiwum Główne Akt Dawnych (toliau $A G A D)$, Archiwum Radziwłów (toliau AR), IV, nr. 17-195. 
negalèjo patenkinti tokie jam siūlomi urèdai kaip Lietuvos iždininkystẻ ar Palenkès vaivadystè. Oficialiai nepereidamas ị opoziciją Augustui II, J. K. Sapiega nenutrauke ryšių su Švedijos ir Stanislovo Leščinskio šalininkais, esančiais Kunigaikštiškojoje Prūsijoje ir Benderuose. Jo ambicijas rode ir tai, kad jis kai kuriuos savo laiškus pasirašydavo kaip Lietuvos didysis etmonas ${ }^{12}$.

1709 m. pabaigoje Sapiegų giminè skilo ị kelias dalis - susitaikymo su Augustu II šalininkus ir to priešininkus. Kazimieras Jonas Sapiega (Kazimierz Jan Sapieha), Vilniaus vaivada ir Lietuvos didysis etmonas iki $1708 \mathrm{~m}$., nuo pat $1709 \mathrm{~m}$. rudens buvo aktyvus susitaikymo šalininkas. Jis 1710 m. dalyvavo Varšuvos konfederacineje taryboje ir, nors ir nerimavo dèl galimų caro ir Rusijos kariuomenès represijų, net nesvarstė galimybių grịžti ị Karolio XII stovyklą. K. J. Sapiega stengèsi išnaudoti savo ryšius su Prūsija-Brandenburgu, kad jos diplomatai padètų atkurti gerą Sapiegų giminès ịvaizdị caro akyse ${ }^{13} .1711 \mathrm{~m}$. balandžio mèn. jis per tarpininkus sieke išsiaiškinti Petro požiūrị i jị ir visą Sapiegų giminę. Galima numanyti, kad šios pastangos buvo sėkmingos: jau po kelių mėnesių K. J. Sapiega gyrèsi gavęs atleidimą nuo Rusijos kariuomenès kontribucijų ${ }^{14}$. Nors ir dažnai kirsdavo Lietuvos sieną lankydamas savo dvarus Žemaitijoje, K. J. Sapiega visam laikui gyventi į Lietuvą iš Kunigaikštiškosios Prūsijos grị̌o tik $1712 \mathrm{~m}$. rudeni.

K. J. Sapiegos sūnūs Lietuvos stalininkas Jurgis Stanislovas ir Lietuvos maršalka Aleksandras Povilas Sapiegos (Jerzy Stanisław Sapieha, Aleksander Pawet Sapieha) taip pat linko taikytis, bet norejo išsaugoti savo urèdus. Tai padaryti buvo keblu, nes valdovas urèdais norejjo apdovanoti savo šalininkus, kurie jam liko ištikimi po Stanislovo Leščinskio išrin-

12 Elžbieta Sieniavska (Elżbieta Sieniawska) Adamui Sieniavskiui (Adam Sieniawski), 1709 m. rugsèjo 13 ir spalio 1 d. laiškai, Biblioteka Czartoryskich (toliau BCzar), b. 5943, nr. 37289, 37293; Jokūbas Zigmuntas Rybinskis (Jakub Zygmunt Rybiński) A. Sieniavskiui, 1709 m. rugsèjo 27 ir spalio 3 d. laiškai, BCzar, b. 5937, nr. 35424-35425; J. K. Sapiega Antanui Kazimierui Sapiegai (Antoni Kazimierz Sapieha), 1713 m. kovo 6 d., Lietuvos mokslu akademijos Vrublevskiu biblioteka (toliau - LMAVB), f. 139, b. 4000/2.

13 K. J. Sapiega Jonui Šembekui (Jan Szembek), 1710 m. vasario 13 d., Polska Akademia Nauk Biblioteka Kórnicka, b. 412, nr. 15; K. J. Sapiega sūnui, 1709 m. lapkričio 15 d., $L M A V B$, f. F139, b. 4064/1.

14 K. J. Sapiega karininkams Bychove, $1711 \mathrm{~m}$. balandžio 6 d. ir gruodžio 11 d. laiškai, $L M A V B$, f. 139, b. 4004/2. 
kimo 1704 m. Todèl iki pat 1712 m. pabaigos K. J. Sapiegos sūnūs, kaip ir jų tèvas, vengè aktyvios politikos ir laukè, kaip toliau klostysis aplinkybès, kokia bus karo eiga ${ }^{15}$. Bet vienas K. J. Sapiegos anūkų, J. S. Sapiegos sūnus, Merkinès seniūnas Antanas Kazimieras Sapiega, nusprendè nepaklusti tèvo ir senelio valiai ir toliau laikytis Stanislovo Leščinskio ir Karolio XII stovyklos. A. K. Sapiegai tèvas priekaištavo, kad jo radikalus elgesys diskredituoja ir stumia ỉ pavojų visą Sapiegų giminę ${ }^{16}$. Kaip minèta, Stanislovui Leščinskiui likusių ištikimų arba jam prijaučiančių dèl asmeninès naudos siekio J. K. ir A. K. Sapiegų prieglobsčio vieta tapo Brandenburgui-Prūsijai priklausanti Kunigaikštiškoji Prūsija, kur pasitrauke ir nedaug Lietuvos kariuomenès karininkų, nenorejjusių pripažinti L. Pociejaus viršenybès ${ }^{17}$.

Tarp kitų švedų šalininkų buvo Lietuvos lauko etmonas, paskirtas Stanislovo Leščinskio, M. S. Višnioveckis, broliai Jurgis Heronimas Krišpinas-Kiršenšteinas (Jerzy Hieronim Kryszpin-Kirszensztein) ir Lietuvos sargybininkas, taip pat paskirtas Stanislovo Leščinskio, Kazimieras Krišpinas-Kiršenšteinas (Kazimierz Kryszpin-Kirszensztein), keliolika žymesnių Lietuvos kariuomenès karininkų: Mikalojus Chmara (Mikołaj Chmara), Jonas Pranciškus Buda (Jan Franciszek Buda) ir kiti. Visi jie, išskyrus J. K. Sapiegą, kuris oficialiai buvo perèjęs ị Augusto II pusę ir kartais atvykdavo ị Lenkiją, nuolatos gyveno Kunigaikštiškojoje Prūsijoje. Iš ten Karolio XII ir Stanislovo Leščinskio šalininkai 1711-1712 m. rengè karinius reidus ị Lietuvos teritorijos gilumą. Tokių Švedijos šalininkų reidų tikslas buvo kelti ịtampą Prūsijos ir Lietuvos pasienyje, skleisti propagandą Lietuvos kariuomenès daliniuose ir prisiplèšti pinigų.

Štai $1711 \mathrm{~m}$. pavasarị Krišpinai-Kiršenšteinai surengè Žemaitijos puolimą, bet joje dislokuotos Augustui II lojalios Lietuvos kariuomenès vèliavos išsklaidè partizanų pajègas ir, vydamosi jas, ịsiveržè ị Kunigaikštiškosios Prūsijos teritoriją. Lietuvos kariuomenès daliniai buvo internuoti ir suimti Prūsijos pasienio pajègų. L. Pociejus parašè laišką,

\footnotetext{
15 Motiejus Ancuta (Maciej Ancuta) K. S. Radvilai, 1712 m. lapkričio 13 d., AGAD, AR V, 126; K. J. Sapiega Lietuvos Vyriausiojo Tribunolo deputatams, 1712 metai, Lietuvos valstybès istorijos archyvas (toliau - LVIA), Senieji aktai (toliau SA), s. 56, 1. 1640-1641.

16 J. S. Sapiega A. K. Sapiegai, 1711 m. liepos 24 d., $L M A V B$, f. 139, b. 4000/1.

17 Šapoka M. Lietuvos Didžiosios Kunigaikštystès kariuomenè 1710-1711 m., Lietuvos istorijos metraštis, 2017 metai, 1 (2017), p. 31.
} 
protestuodamas prieš tokị Prūsijos-Brandenburgo pareigūnų elgesị ir reikalaudamas paleisti Lietuvos kariuomenès karius ị laisvę, o Švedijos šalininkus - išvyti iš šalies teritorijos ${ }^{18}$. Pasienyje su Prūsija buvo išdèstyti Lietuvos kariuomenės sargybos postai, kurie turèjo užkirsti kelią partizanų išpuoliams, bet iš istoriniuose šaltiniuose pateiktų nusiskundimų aiškẻja, kad jie nevengè stabdyti ir plešti ir niekuo dètų asmenų. Tarp sustabdytų nukentejusiųjų buvo Vilniaus vaivada K. J. Sapiega, Polocko vaivada Dominykas Sluška (Dominik Stuszka) ir kiti ${ }^{19}$. Lietuvos pasienio muitinès buvo ypač patrauklus partizanų plešimų objektas, nes buvo arti pasienio, prastai saugomos ir vienas iš nedaugelio grynųjų pinigų šaltinių XVIII a. pradžios Lietuvoje.

Istoriniuose šaltiniuose užfiksuotas ne vienas Jurbarko ir Virbalio muitinių apiplěšimas $1711 \mathrm{~m}$. Nuostoliai ịvertinti maždaug 8 tūkstančiais auksinų ${ }^{20}$. Partizanai taip pat nevengdavo susirinkti hibernos mokesčių iš valstybinių dvarų Žemaitijoje ${ }^{21}$. Istoriniuose šaltiniuose išlikęs pasakojimas, kaip 1711 m. rugsèjo 4 d. netoli Raigardo, prie Prūsijos sienos, vienas iš brolių Krišpinų-Kiršenšteinų ir M. S. Višnioveckis Lietuvos kariuomenès daliniams pasiūlè 100 tūkstančių auksinų, kad šie pereitų i Stanislovo Leščinskio pusę. Tautinio autoramento vèliavos buvo linkusios priimti pasiūlymą, bet vienas svetimšalių autoramento karininkas užkirto tam kelią. Kai Augustas II išgirdo apie šị nutikimą ir karininko žygdarbị, pareiške jam dovanosiantis pirmą atsilaisvinusią karališkąją seniūnijąa ${ }^{22}$.

18 Džordžas Makenzis (George Mackenzie) Džeimsui Duglasui (James Douglas), $1711 \mathrm{~m}$. balandžio 14 d., The National Archives in Kew (toliau TNA), State papers (toliau - SP) 88, b. 18 (visos datos pateikiamos naujuoju stiliumi); L. Pociejus K. S. Radvilai, $1711 \mathrm{~m}$. gegužès 21 d., $A G A D$, AR V, b. 11913.

19 K. J. Sapiega Lietuvos Vyriausiojo Tribunolo deputatams, 1712 metai, LVIA, SA, b. 56, 1. $1640-1641$.

${ }^{20}$ Kazimieras Pociejus Stanislovui Denhofui, 1711 m. lapkričio 13 d., BCzar, b. 5915, nr. 29956; Summaryusz Calculacyey ex perceptis et distributis Importancyi dwuletney $z$ prowentow Rzeczypospolitey WXL mianowicie cła nowopodwyższonego, donativum Kupieckiego, y monopolium tabacznego (senasis spaudinys).

21 S. Denhofas A. Sieniavskiui, 1711 m. spalio 16 d., BCzar, b. 5791, nr. 7693.

22 L. Pociejus J. Šembekui, 1711 m. spalio 12 d., BCzar, b. 493, nr. 70; S. Denhofas K. S. Radvilai, 1711 m. rugsèjo 10 d., AGAD, AR V, b. 2956; J. Šembekas K. S. Radvilai, 1711 m. spalio 6 d., $A G A D$, AR V, b. 15699. 
J. K. Sapiega 1711 m. išlaikè nemažą palydą - nuo kelių šimtų iki kelių tūkstančių karių, o pats būdavo arba Kunigaikštiškojoje Prūsijoje, arba netoli jos. Pajėgos laikėsi miškuose. Jos kelių dešimčių kilometrų spinduliu turèjo išdėsčiusios savo žvalgus, kurie perspėdavo apie artèjančią Rusijos kariuomenę ${ }^{23}$. Nors J. K. Sapiega buvo iš turtingos giminės, joks Respublikos didikas negalèjo ilgai turèti privačios kariuomenès. Tai buvo imanoma tik trumpą laiką, vèliau tokių dalinių išlaikymą tekdavo perleisti valstybei.

Broliai Krišpinai-Kiršenšteinai ir M. S. Višnioveckis puldinejjo Žemaitiją, o J. K. Sapiegos pajėgos veikè pietų kryptimi: Mazovijos, Kulmo, Plocko ir kitose vaivadijose. $1711 \mathrm{~m}$. rudeni šios J. K. Sapiegos pajègos kelis kartus buvo išsklaidytos Lenkijos ir Lietuvos kariuomenių. Pats J. K. Sapiega nedalyvaudavo žygiuose ir buvo nepatenkintas, kai jo pajẻgos, kurias jis oficialiai skelbẻ laikąs savo saugumui užtikrinti, buvo puolamos $^{24}$.

Augustui II ištikima Lietuvos kariuomenè 1710-1711 m. buvo smarkiai padidinta, bet sumokèti jos kariams trūko pinigų ${ }^{25}$. Tad nepatenkinti daliniai buvo partizanų propagandos objektas. Jie buvo kviečiami sukelti maištą ir pereiti ị Stanislovo Leščinskio pusę. Ypač partizanus domino svetimšalių autoramento daliniai, kurių karinẻ vertẻ buvo pati didžiausia. L. Pociejus buvo sunerimęs dèl tokių veiksmų ir liepè griežtai bausti už bet kokias sentimentų švedų šalininkams apraiškas Lietuvos kariuomenès daliniuose. Keli partizanų pasiuntiniai, bandę sukelti maištą Lietuvos kariuomeneje, buvo pagauti ir nubausti mirties bausme ${ }^{26}$. Kai

${ }_{23}$ Tomašas Gintautas (Tomasz Gintowt) K. S. Radvilai, 1710 m. rugpjūčio 13 d., AGAD, AR V, b. 4204; Fiodoras Balkas (Федор Балк) Petrui I, 1711 m. rugsëjo 17 d., Письма и бумаги Императора Петра Великого, т. 11, вып. 2, Москва, 1964, с. 429; L. Pociejus J. Šembekui, 1711 m. spalio 12 d., BCzar, b. 493, nr. 70.

${ }^{24}$ L. Pociejus K. S. Radvilai, 1711 m. rugsèjo 29 d., AGAD, AR V, b. 11913; A. Sieniavskis J. Šembekui, 1711 m. spalio 5 d., BCzar, b. 461, nr. 13; L. Pociejus J. Šembekui, 1711 m. lapkričio 4 d., BCzar, b. 461, nr. 54; D. Makenzis D. Duglasui, 1711 m. liepos 17 d., TNA, SP 88, b. 19; D. Makenzis Henriui Seint Džonui (Henry St. John), 1711 m. spalio 30 d., TNA, SP 88, b. 19; J. Z. Rybinskis A. Sieniavskiui, 1711 m. lapkričio 28 d., BCzar, b. 5937, nr. 35477.

${ }^{25}$ Plačiau apie tai žr.: Šapoka M. Lietuvos Didžiosios Kunigaikštystės kariuomenė 17101711 m., p. 32-38.

${ }^{26}$ L. Pociejus K. S. Radvilai, 1711 m. gegužès 21 d. ir gruodžio 10 d. laiškai, $A G A D$, AR V, b. 11913; K. S. Radvilai S. Denhofui (?), 1711 m. rugpjūčio 4 d., BCzar, b. 5928, nr. 33198. 
1712 m. pradžioje Lietuvos iždo tribunole buvo nutarta Lietuvos kariuomenę sumažinti, L. Pociejus nusprendè nepaklusti šiam nurodymui, bijodamas, kad paleisti iš tarnybos kariai, kuriems valstybe buvo ịsiskolinusi, neprisijungtų prie J. K. Sapiegos. O paliktus tarnauti buvo galima išlaikyti savo stovykloje, nes kiekvienas karys tikejjosi atgauti užtarnautus pinigus. Paleidimas iš tarnybos būtų reiškęs, kad šie kariai tikrai negalès atgauti jiems už ištarnautą laiką priklausančio užmokesčio. Nevykti ị $1712 \mathrm{~m}$. balandžio mèn. sušauktą Respublikos seimą nusprendęs L. Pociejus paprašé Lietuvos kanclerio K. S. Radvilos pasirūpinti, kad jame būtų priimta konstitucija, kuri visus tuos, kurie kelia vidinius neramumus ir formuoja neaiškios paskirties karinius vienetus, paskelbtų tėvynès priešais ir nurodytų konfiskuoti jų valdas ${ }^{27}$.

Paradoksalu, bet kviečiamiems pereiti ị jų pusę Lietuvos kariuomenès daliniams švedų šalininkai nelabai turèjo ką pasiūlyti, nes, kaip jų korespondencija rodo, patys jaute katastrofišką pinigų trūkumąą ${ }^{28}$ „Mes pralaimejome savo kovą ir neturime jokios vilties vèl prisikelti“, - taip vaizdžiai švedų šalininkų padett̨ $1711 \mathrm{~m}$. pabaigoje Prūsijoje apibūdino vienas iš Krišpinų-Kiršenšteinų šeimos narių ${ }^{29}$.

Švedų šalininkų, gyvenančių Kunigaikštiškosios Prūsijos teritorijoje, padèti $1711 \mathrm{~m}$. pabaigoje pablogino ir besikeičiančios diplomatinès aplinkybès. Prūsijos ir Švedijos santykiai blogèjo pirmiausia dèl to, kad Prūsija-Brandenburgas, matydama Švedijos silpnèjimą, pradèjo kurti jos teritorijų Pamaryje užèmimo planus. Todèl Brandenburgo-Prūsijos vadovybe, iki tol buvusi gana tolerantiška lietuviams, Švedijos šalininkams, gyvenantiems jos teritorijoje, $1711 \mathrm{~m}$. pabaigoje ima svarstyti planus, kaip jų būtų galima atsikratyti.

Nepavykus 1711 m. sukelti maišto Lietuvos kariuomenèje, M. S. Višnioveckis paliko Kunigaikštiškają Prūsiją ir 1712 m. pradžioje nukeliavo i Benderus. J. K. Sapiega pasiliko kur buvęs ir $1712 \mathrm{~m}$. planavo naujus veiksmus. Abi pusès - partizanai ir Augusto II šalininkai - suprato, kad $1712 \mathrm{~m}$. karinè kampanija iš esmès bus paskutinis bandymas ịvykdyti perversmą Lenkijos ir Lietuvos teritorijoje. Jeigu jis nepavyks, Švedijos

\footnotetext{
27 L. Pociejus K. S. Radvilai, 1712 m. kovo 6 ir 29 d. laiškai, AGAD, AR V, b. 11913.

28 J. P. Buda karininkui, 1712 m. rugsèjo 7 d., $L M A V B$, f. 139, b. 432.

29 Vienas iš Krišpinų-Kiršenšteinų A. K. Sapiegai (?), 1711 m. gruodžio 22 d., LMAVB, f. 139 , b. 2328 .
} 
šalininkai turès arba susitaikyti su Augustu II, arba pasitraukti iš Brandenburgo-Prūsijos teritorijos ị Švediją arba Osmanų imperiją.

Sunku pasakyti, kiek švedų šalininkai 1710-1711 m. tikejjo Švedijos perspektyvomis Didžiajame Šiaurès kare ir kokios priežastys lèmè, kad jie neperejo ị Augusto II pusę. Kaip minèta, Poltavos mūšis, nors ir didelè Rusijos kariuomenès pergalè, amžininkams neatrodè nuosprendis, t. y. kad Švedijos karinė galybė gali būti sutriuškinta viename mūšyje. Papildomas veiksnys, vertęs likti švedų šalininkų stovykloje, buvo M. S. Višnioveckio likimas - jis, nors ir amnestuotas, buvo suimtas Rusijos kariuomenès. Asmenys, vis dar prijaučiantys Stanislovui Leščinskiui, bet kuriuo atveju negalejo jaustis saugūs net ir nebūdami Lietuvoje. Štai $1710 \mathrm{~m}$. Kunigaikštiškojoje Prūsijoje Rusijos kariuomenès dalinys užpuole kaimą, kuriame slèpèsi broliai Krišpinai-Kiršenšteinai. Jie vos sugebejo pasprukti nuo rusų, bet turejjo palikti visus savo daiktus ${ }^{30}$. Dar viena priežastis, vertusi laikytis Švedijos, buvo tai, kad perejjus ị Augusto II pusę grèsė prarasti turimas pareigybes. 1704-1709 m. susiklostè tokia situacija, kad Respublikoje buvo du valdžios centrai: Augustas II ir ji remianti Sandomiro konfederacija ir Stanislovas Leščinskis, taip pat ji remianti Varšuvos konfederacija. Abi pusés skyrè saviškius i tuos pačius urèdus, o po to tie asmenys tarpusavyje konkuruodavo. Todèl perejimas $\mathfrak{i}$ kitą pusę reiškè neišvengiamą pretenzijų i turimą urèdą atsisakymą; kita vertus, dèl svarbių urẻdų trūkumo buvo neįmanoma kitos pusės žymesnių asmenų sugundyti ir pervilioti ị savo pusę. Štai $1711 \mathrm{~m}$. pabaigoje Lietuvos didysis etmonas L. Pociejus pasiuntè Žemaitijos seniūną Kazimierą Zaranką (Kazimierz Zaranek) pas M. S. Višnioveckį, kad pasiūlytų jam pereiti ị Augusto II pusę. Nèra detalesnių duomenų apie derybų eigą, tik žinoma, kad jos žlugo ${ }^{31} .1712 \mathrm{~m}$. derybos dèl Augusto II pripažinimo vyko ir tarp dviejų didžiausių priešų - L. Pociejaus ir J. K. Sapiegos, tarpininkaujant Lietuvos kariuomenès generolui majorui ir Lietuvos lauko raštininkui Mykolui Juozapui Sapiegai (Michał Józef Sapieha). Turimi istoriniai šaltiniai neatskleidžia konkrečių J. K. Sapiegos iškeltų sąlygų, tačiau, pasak L. Pociejaus, J. K. Sapiegos norai buvo pernelyg dideli ir net apaštalų ikkal-

30 Mikalojus Petrusevičius (Mikołaj Petrusewicz) K. S. Radvilai, 1710 m. gegužès 1 ir 14 d. laiškai, $A G A D$, AR V, b. 11536.

31 S. Denhofas J. Šembekui, 1711 m. lapkričio 20 d., BCzar, b. 488, nr. 71. 
binèjimai nebūtų ịtikinę jo susitaikyti su Augustu II ${ }^{32}$. J. K. Sapiega rašè, kad jam jau pakaks „Pono, esančio Rytuose“ (Karolio XII - M. Š.), pažadų, jeigu tik gaus to, ko nori ${ }^{33}$. Yra pakankamai duomenų, kad Vilniaus vaivados K. J. Sapiegos sveikata smarkiai pablogèjo $1711 \mathrm{~m}$. pabaigoje, todèl visas šias derybas galima sieti su šia pareigybe. Tikètina, kad Vilniaus vaivadystė būtų patenkinusi J. K. Sapiegą, bet L. Pociejus, išgirdęs apie pablogèjusią Vilniaus vaivados sveikatą, iš karto èmè telkti šalininkus, kurie paremtų valdovo dvare jo siekị gauti Vilniaus vaivadiją ${ }^{34}$.

\section{J. GRUDZINSKIO İSIVERŽIMAS İ LENKIJĄ}

Po Poltavos pergalès Rusijos veiksmus prieš Švediją komplikavo Osmanų imperijos įsikišimas ị Didijj Šiaurès karą. $1711 \mathrm{~m}$. Rusijos ir Osmanų imperijos karas baigèsi Pruto taika, pagal kurią Rusija įsipareigojo išvesti savo kariuomenę iš Respublikos. Bet ji delsè tai padaryti. Osmanų imperijos valdžia, matydama, kad Rusija nevykdo šios ir kitų Pruto taikos sąlygų, ėmè ruoštis naujam karui, o Švedijos karalius su savo šalininkais vis dar buvo turkų teritorijoje. Rusija siekè $1712 \mathrm{~m}$. tęsti jau pradètą Suomijos, priklausančios Švedijai, užkariavimą ir išstumti Švediją iš pietinio Baltijos jūros regiono - Pamario. Augusto II užsienio politika kelerius metus grịžus ị sostą buvo nukreipta ị Švedijai priklausančias Pamario teritorijas. Kai Rusija 1710 m. užèmè Rygą ir Livoniją, buvo mažai tikètina, kad Rusija šias teritorijas perduos Respublikai arba Saksonijai, nors tai ji ir turejo padaryti pagal ankstesnes sutartis. Todèl vienintelis būdas Augustui II ką nors laimèti kare buvo užimti dali Švedijos Pamario. Tuo metu Respublikos bajorijos, kuri rèmė valdovo siekius tęsti karą, dèmesys vis dèlto buvo sutelktas ị turkų pavojų ir Rusijos kariuomenès kontribucijas. Visomis priemonėmis buvo siekiama išvengti karo su Osmanų imperija ir priversti Rusiją išvesti savo kariuomenę iš Respublikos teritorijos.

32 „Widzę y na żadne Apostolskie perswuazie podobnoby niesupersedowali a to naybarziey widzę że tak maią do KJM zepsowane serce że żadno miaro subesse niechcą" L. Pociejus A. Sieniavskiui, 1712 m. liepos 4 d., BCzar, b. 5916, nr. 30066.

33 J. K. Sapiega A. K. Sapiegai, 1712 m. vasario 16 d., $L M A V B$, f. 139, b. 4000/2.

34 L. Pociejus K. S. Radvilai, 1711 m. spalio 25 d., AGAD, AR V, b. 11913. 
Karolis XII nesvarstė galimybės sudaryti taiką su Rusija, nes reikètų jai atiduoti dalị prarastų teritorijų, greičiausiai Ingriją ir Livoniją. Nors Švedijos karine padetis prastejo, Karolis XII buvo pasiryžęs tęsti karą. $1711 \mathrm{~m}$. Švedija perejo ị gynybinị karą. $1711 \mathrm{~m}$. jungtinès Rusijos, Danijos ir Saksonijos pajègos sèkmingai puolè Švedijos Pamario miestus. Pagrindinis sąjungininkų tikslas buvo užimti Štralzundą ir Ščeciną. Švedijos kariuomenès igula Štralzunde atkakliai gynėsi, nes tikejjosi, jog greitai iš Švedijos bus atplukdytas kariuomenès korpusas, kuris įveiks sąjunginkus ir nutrauks apgulą.

Karolio XII, Stanislovo Leščinskio ir jų šalininkų kariniame $1712 \mathrm{~m}$. kampanijos plane buvo numatyta pereiti iš gynybos i puolimą. Karolis XII ir J. Potockis planavo iš Osmanų imperijos į Lenkijos karalystès teritoriją nukreipti kavalerijos junginius. İsiveržę i krašto gilumą, jie turèjo prikaustyti Lenkijos kariuomenès dèmesị. Tuo pat metu Švedijos kariuomenès desantas, vadovaujamas Magnuso Stenboko (Magnus Stenbock), turejo išsilaipinti Pamaryje, sumušti jungtinę Saksonijos, Rusijos ir Danijos kariuomenę ir įsiveržti ị Lenkiją, o Osmanų imperija, turinti pulti Rusiją ir dešiniakrantę Ukrainą arba duoti pakankamai stiprią palydą, maždaug penkiasdešimt tūkstančių karių, Karoliui XII grižži ị Švediją per Respublikos teritoriją ir issitraukti ị karą. Tuo pat metu J. K. Sapiega su savo surinktais daliniais iš Kunigaikštiškosios Prūsijos pultų Lietuvą. Puolant Augustą II iš kelių pusių buvo tikimasi nuversti jị nuo sosto ir $\mathfrak{i}$ ji sugrąžinti Stanislovą Leščinskị, taip pat igyti iniciatyvą kare, kuris vis labiau krypo sąjungininkų naudai ${ }^{35}$.

1712 m. vasario mèn. pradejjo veikti Švedijos šalininkai Benderuose. Iš pradžių buvo išleistas manifestas, kuriame Augustas II buvo vadinamas sosto uzurpatoriumi ir Respublikos teisių pažeidèju. Manifeste buvo protestuojama prieš Augusto II valdžią, o jo sąjungininkè Rusija vadinama didžiausiu Respublikos priešu. Švedijos šalininkų ambicijas perimti valdžią Respublikoje rodè ir tai, kad manifestą pasirašę J. Potockis ir M. S. Višnioveckis save titulavo Lenkijos ir Lietuvos didžiaisiais etmonais. Lietuvos pusei atstovavo ir manifestą taip pat pasirašè broliai J. H. ir K. Krišpinai-Kiršenšteinai, $1712 \mathrm{~m}$. pradžioje nuvykę i Benderus ${ }^{36}$. Be to,

35 Wagner M. Zagon Kawaleryjski Jana Grudzińskiego w 1712 roku, s. 212; Jarochowski K. Wycieczka Grudzińśkiego, starosty Rawskiego' do Polski w roku 1712, s. 359-360.

36 Švedų šalininkų manifestas, 1712 m. vasario 18 d., BCzar, b. 559, k. 183-186. 
buvo tikimasi, kad, Lietuvoje pasirodžius švedụ šalininkų daliniams ir pačiam Karoliui XII, Lietuvos kariuomene, ištikima L. Pociejui, pereis ¡ Švedijos karaliaus pusę $e^{37}$. Buvo stengiamasi šiuos karinius ir politinius tikslus kuo plačiau paskleisti Respublikoje skelbiant manifestus.

$1712 \mathrm{~m}$. vasario mèn. iš Benderų i Lenkiją buvo pasiųstas maždaug 2000 raiteliu dalinys, vadovaujamas Kristupo Urbanovičiaus (Krzysztof Urbanowicz). Jis turèjo būti kaip priedanga pagrindinèms pajègoms, vadovaujamoms Jono Grudzinskio (Jan Grudzyński) ${ }^{38}$. Kovo viduryje J. Grudzinskis su maždaug 5000 raitelių ịkūrè savo bazę Pokutijoje, istorinèje Moldavijos kunigaikštystės teritorijoje (dabartinė Ukraina), Pruto upès aukštupyje, Lenkijos karalystès pasienyje. $1712 \mathrm{~m}$. kovo 15-17 d. daliniai kirto Lenkijos sieną ir ịsikūrẻ pasienyje, neskubẻdami žygiuoti ị krašto gilumą, o po poros savaičių J. Grudzinskis su savo daliniais apsisuko ir grịžo ị Pokutiją.

Istoriografijoje aiškinama, kad J. Grudzinskis nesiveržè gilyn ị Lenkiją, nes tam buvo nepalankios oro sąlygos, jo kariuomenei trūko savanorių ir pinigų ${ }^{39}$. Visgi verta atkreipti dèmesį, kad balandžio mèn. Varšuvoje vyko Respublikos seimas. Visuotinis nepasitenkinimas Rusijos kariuomene galëjo susilpninti valdovo Augusto II ketinimus tęsti karo veiksmus ir pasitarnauti švedų partizanams. $1712 \mathrm{~m}$. balandžio $20 \mathrm{~d}$. seimas baigèsi - buvo atidètas iki tų pačių metų gruodžio pabaigos. Iš esmès seimas neprièmé jokių sprendimų dèl mokesčiu ir neišsprendè Lenkijos ir Lietuvos kariuomenių finansavimo problemos. Be to, nebuvo žengta reikiamų žingsnių, siekiant panaikinti švedų partizanų pavojų - iš karto po seimo buvo pasirašytos amnestijos švedų šalininkams, tačiau nèra duomenų, kad kas nors jomis būtų iš karto pasinaudojęs ${ }^{40}$.

Gegužès pabaigoje švedų šalininkai nusprendè J. Grudzinskio kavalerijos dalinius nukreipti ị Didžiosios Lenkijos, kuri 1704-1706 m. buvo vienas iš opozicijos Augustui II židinių, teritorijas. $1712 \mathrm{~m}$. gegužès 12-13 d. J. Grudzinskio daliniai, kuriuos sudarè apie 6-7 tūkstan-

\footnotetext{
37 L. Pociejus K. S. Radvilai, 1712 m. kovo 5 d., AGAD, AR V, b. 11913.

38 Wagner M. Zagon Kawaleryjski Jana Grudzińskiego w 1712 roku, s. 212.

39 Ibid., s. 213; Jarochowski K. Wycieczka Grudzińśkiego, starosty Rawskiego, do Polski w roku 1712, s. 366-367.

40 Amnestija M. S. Višnioveckiui, 1712 m. birželio 12 d., LVIA, Lietuvos Metrika (mikrofilmai) (toliau - LM), b. 155, 537-539.
} 


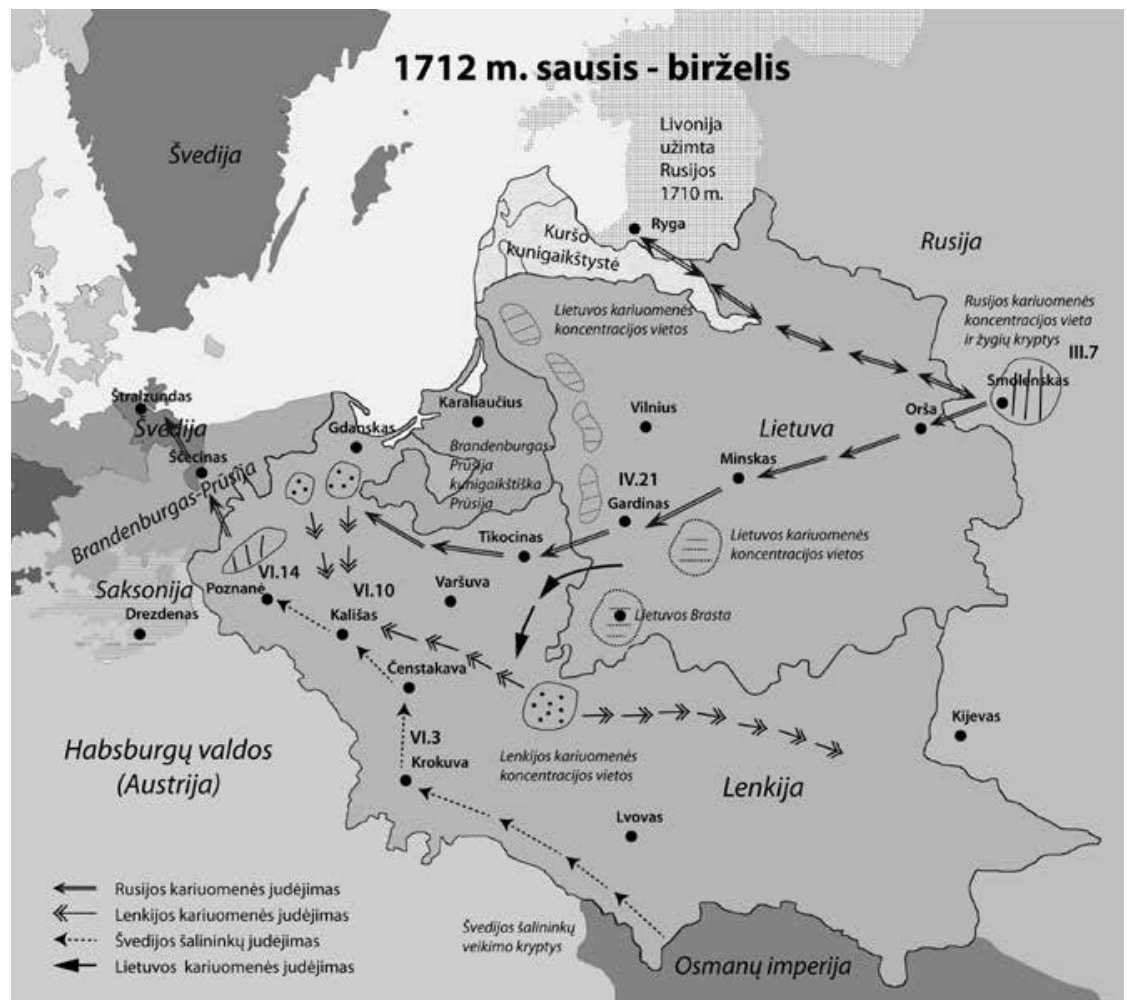

1 pav. Kariuomenès dislokacijos vietos ir judejjimo kryptys $1712 \mathrm{~m}$. sausio - birželio mèn.

čiai raitelių, kirto Moldavijos sieną. Gegužès 23 d. jie pasiekė Peremyšli (Przemyśl), o gegužès 29 d. jau buvo prie Tarnuvo (Tarnów) ir birželio 3 d. persikèlè per Vyslą prie Tynieco (Tyniec). Iš ten žygiuota šiaurès vakarų kryptimi link Kališo ir jo apylinkès pasiektos birželio $10 \mathrm{~d}$. Per maždaug 30 dienų kavalerijos daliniai nužygiavo apie $900 \mathrm{~km}, \mathrm{t}$. y. apie $30 \mathrm{~km}$ per dieną ${ }^{41}$.

Žygiuojančios J. Grudzinskio pajègos nesutiko jokio Lenkijos ar Rusijos kariuomenès pasipriešinimo. 1712 m. gegužès mèn. Lenkijos kariuomenè tuo metu buvo padalyta $\mathfrak{i}$ dvi dalis. Pagrindinès pajègos, maždaug

41 Wagner M. Zagon Kawaleryjski Jana Grudzińskiego w 1712 roku, s. 214; Jarochowski K. Wycieczka Grudzińśkiego, starosty Rawskiego, do Polski w roku 1712, s. 366-372. 
12 tūkstančių karių, stovèjo šalies pietryčiuose prie Tarnogūros (Tarnogóra), bet Lenkijos didysis etmonas A. Sieniavskis dali jų nukreipé i Ukrainą, kur kilo kazokų maištas. J. Grudzinskị Didžiojoje Lenkijoje pasitiko Lenkijos kariuomenés dalis, vadovaujama J. Z. Rybinskio, apie 5-6 tūkstančius karių. Taip pat prieš J. Grudzinskị buvo nukreipti maždaug 5 tūkstančiai pagrindinès Lenkijos kariuomenès divizijos karių ${ }^{42}$. Tokị Lenkijos ir Rusijos kariuomenių pasyvumą galima aiškinti informacijos trūkumu. Nežinota, ar J. Grudzinskio dalinių neseka pagrindinès turkų pajègos, taip pat galvota, kad pats Karolis XII inkognito gali dalyvauti J. Grudzinskio žygyje - tokiu atveju pagal taikos tarp Rusijos ir Osmanų imperijos sąlygas būtų reikèję ji praleisti iki Švedijos ${ }^{43}$.

Pasiekus Kališą, nuspręsta tęsti puolimą link Poznanès, ir ji buvo pasiekta birželio $13 \mathrm{~d} .{ }^{44}$ Čia J. Grudinskis savo pajeggas padalijo i̇ dvi dalis: pagrindinès pajègos, jo paties vadovaujamos, pasiliko prie Poznanès stebėti Rusijos kariuomenès iggulos veiksmų, o mažesnès, vadovaujamos K. Urbanovičiaus, turëjo žygiuoti ị Šiaurès vakarus Baltijos jūros link, siekdamos gauti žinių apie planuojamą Švedijos kariuomenès desantą. Iš tikrụjų Švedijai trūko išteklių, kad galètų greitai pasiruošti desanto išsilaipinimui, tad jis ị Riugeno salą atvyko tik rugsèjo pabaigoje.

Nužygiavus pajègoms apie $100 \mathrm{~km}, \mathrm{~K}$. Urbanovičius gavo žinių, kad Rusijos ir Lenkijos kariuomenès planuoja apsupti J. Grudzinski prie Poznanès. K. Urbanovičius pasuko atgal ir birželio $20 \mathrm{~d}$. grižo i̇ pagrindinę stovyklą prie Poznanės ${ }^{45}$. Tuo metu Lenkijos kariuomenès pagrindinès divizijos daliniai jau buvo prie Pyzdrių (Pyzdry), i pietryčius nuo Poznanès, o J. Grudzinskis atsitraukè ị V̌̌ešnią (Września), kurią pasieke birželio 24-25 d. Istoriografijoje teigiama, jog J. Grudzinskis turejo informacijos, kad prie Gniezno, maždaug $25 \mathrm{~km}$ ị šiaurę nuo Vžešnios, neva stovejjo J. K. Sapiegos daliniai, norintys susijungti su jo pajègomis $^{46}$.

\footnotetext{
42 Wagner M. Zagon Kawaleryjski Jana Grudzińskiego w 1712 roku, s. 214-215.

43 Jarochowski K. Wycieczka Grudzińskiego, starosty Rawskiego, do Polski w roku 1712, s. $373-374$.

44 Wagner M. Zagon Kawaleryjski Jana Grudzińskiego w 1712 roku, s. 215.

45 Ibid., s. 216.

46 Ibid., s. 216-217.
} 
Žinoma, jokių J. K. Sapiegos dalinių netoliese nebuvo, o Rusijos kariuomenès dalinys birželio $26 \mathrm{~d}$., žygiuodamas nuo Pyzdrių, užpuolè prie Vžešnios vis dar esančius J. Grudzinskio dalinius ${ }^{47}$. Bijodamas apsupimo, J. Grudzinskis buvo priverstas trauktis ị pietus, link Silezijos, priklausančios Habsburgams. Tuo metu Rusijos ir Lenkijos kariuomenių daliniai siekè užtverti kelią, kad partizanai nepabègtų iš šalies. Lemiamas susidūrimas ịvyko prie Krotošyno (Krotoszyn) miesto. Lenkijos kariuomenès ir J. Grudzinskio dalinių karių skaičius buvo panašus - apie 5-6 tūkstančiai kavalerijos raitelių. J. Grudzinskis nenorejo kautis, buvo pradètos derybos, o pasirodžius Rusijos kavalerijos daliniams, partizanai po trumpo mūšio èmè trauktis ir bėgti link Silezijos. J. Grudzinskis birželio pabaigoje su nedideliu būriu kirto Lenkijos sieną ir vèl pasirodè prie Čestakavos, bet liepos pradžioje atsitrauke link Krokuvos ir grižo ị Benderus ${ }^{48}$. Taip J. Grudzinskio žygis baigèsi visiška nesėkme. Kol nebuvo didelių priešų pajėgų, J. Grudzinskis laisvai manevravo ir ịsiveržè ị krašto gilumą, bet, neatvykus Švedijos kariuomenès desantui, neturejo jokių šansų pasipriešinti jungtinèms Lenkijos ir Rusijos kariuomenių pajėgoms.

\section{ŠVEDŲ PARTIZANŲ İSIVERŽIMAS İ LIETUVĄ}

1712 m. balandžio mėn. L. Pociejus buvo ịsitikinęs, kad J. K. Sapiega su savo turimomis pajègomis bandys destabilizuoti padètį Lietuvoje: ịsiveržti ị šalies vidų ir galbūt sukurstyti bajoriją ir Lietuvos kariuomenès dalinius prieš Augustą II ir didžiojo etmono, t. y. L. Pociejaus, valdžią. Dèl to L. Pociejus stengèsi kuo greičiau sutelkti savo turimas Lietuvos kariuomenès pajėgas. Greičiausiai bijodamas J. K. Sapiegos veiksmų, jis nevyko ir ì Varšuvoje sušauktą seimą. Norėdamas užkirsti kelią bajorų, kurie galètų paremti J. K. Sapiegą, susibūrimams, Augustas II, greičiau-

\footnotetext{
47 Taip pat nèra istorinių šaltinių, kurie liudytų, kad kas nors iš lietuvių, prijaučiančių Švedijai, prisijungè prie J. Grudzinskio. Kiti šaltiniai nepatvirtina vadinamųjų Erazmo Otvinovskio (Erazm Otwinowski) atsiminimų teiginio, kad prie J. Grudzinskio buvo prisijungęs Jurgis Felicijonas Sapiega (Jerzy Felicjan Sapieha), J. K. Sapiegos brolis. Žr.: Pamiętniki do panowania Augusta II, napisane przez niewiadomego autora (podobno Erazma Otwinowskiego), wyd. E. Raczyński, Poznań, 1838, s. 203.

48 Ibid., s. 221.
} 
siai L. Pociejaus prašymu ir iniciatyva, išleido universalą, kuriuo bajorijai buvo uždrausta rinktis i savavališkus suvažiavimus be valdovo sutikimo ${ }^{49}$. Birželio $9 \mathrm{~d}$. prie Lietuvos Brastos jau buvo sutelkta 10 svetimšalių autoramento regimentų ${ }^{50}$.

Čia reikètų nuodugniau panagrinèti ir Lietuvos kariuomenès organizavimo ypatumus. Lietuvos kariuomenès būklès ir organizavimo 1710$1711 \mathrm{~m}$. klausimai buvo aptarti anksčiau ${ }^{51}$. O $1712 \mathrm{~m}$. Lietuvos kariuomené buvo organizuojama remiantis tų metų sausio-vasario mèn. Vilniuje posèdžiavusio Lietuvos Didžiosios Kunigaikštystès iždo tribunolo nutarimais. Kadangi $1710 \mathrm{~m}$. Varšuvos konfederacinès tarybos paskirti mokesčiai jau buvo pasibaigę, pinigų kariuomenei labai trūko, o bajorijos atstovai dèl šalies nuniokojimo Iždo tribunole siekè kuo labiau sumažinti dūmų (apmokestinimo vienetų) skaičiu pavietuose, kad reikètų mokèti kuo mažiau mokesčių. Bajorijos atstovai pyko ant L. Pociejaus dèl nesibaigiančiu kariuomenès plěšikavimų, taip pat reikalavo, kad kariuomenè ir aukštų karininkų skaičius būtų sumažintas. Tribunole pasiektas susitarimas numatè, kad kariuomenè bus šiek tiek sumažinta: tautinio autoramento kavalerijos vèliavose, kurias sudare 100 raitelių, turèjo „popieriuje“ likti 80 , o svetimšalių autoramento péstininkų regimentuose - po 400 etatų $^{52}$.

Yra amžininkų liudijimų, kurie rodo, kad kariuomenès būklè $1712 \mathrm{~m}$. buvo pablogèjusi: „Lietuvos kariuomenè koncentruojasi prie Lietuvos Brastos ir Želvos. Kai kuriuose regimentuose daugiau karininkų negu eilinių kareivių. Kariai slankioja be tinkamų uniformų ir ekipiruotès. " ${ }^{53}$ L. Pociejaus nuomone buvo kiek kitokia. Pasak jo, liepos viduryje jo pajẻgas sudare apie 6000 gerai parengtų karių, iš jų - 3000 svetimšalių au-

49 Pociejus, 1712 m. birželio 22 d., BCzar, b. 462, k. 589-591; Augusto II manifestas, 1712 m. birželio 12 d., AGAD, AR II, b. 2236; L. Pociejus A. Sieniavskiui, 1712 m. liepos 10 d., BCzar, b. 5916, nr. 30068.

${ }^{50}$ L. Pociejus K. S. Radvilai, 1712 m. kovo 29-balandžio 21 d. laiškai; L. Pociejus A. Sieniavskiui, 1712 m. birželio 9 d., BCzar, b. 5916, nr. 30061.

51 Šapoka M. Lietuvos Didžiosios Kunigaikštystès kariuomenè 1710-1711 m., p. 30-38.

52 Plačiau apie tai žr.: Šapoka M. Warfare, Loyalty and Rebellion: The Grand Duchy of Lithuania and the Great Northern War, 1709-17. London, New York, NY, 2018, p. 113-114.

${ }_{53}$ M. Ancuta K. S. Radvilai, 1712 m. gegužès 25 d., AGAD, AR V, b. 126. 
toramento karių ${ }^{54}$. Reikia pabrèžti, kad tai nebuvo visos Lietuvos kariuomenès pajègos. Žinoma, kad dar gegužès mèn. maždaug 30 lengvosios kavalerijos vėliavų buvo pasiųstos ị Lenkiją, ị pagalba Lenkijos kariuomenei ${ }^{55}$. L. Pociejus kariuomenès prašè, kad ši būtų kantri ir lauktų atlyginimų, kuriuos Respublika tikrai sumokès. Anksčiau neva valstybẻ buvo jai įsiskolinusi ir 10 metų atlyginimus, tačiau skolas grąžino ${ }^{56}$.

Nèra tikslių duomenų apie Lietuvos kariuomenès karių skaičių $1712 \mathrm{~m}$. Lietuvos kariuomenès etatinè sudètis, kurią, remiantis kitais šaltiniais galima datuoti $1713 \mathrm{~m}$. pavasariu, rodo, kad ją "popieriuje“ tuo metu sudare 670 husarų, 2490 petyhorų, 2190 lengvosios kavalerijos raitelių, maždaug 5300 dragūnų, 5300 pėstininkų ir 420 vengrų pėstininkų. Tiek šių etatų nurodyta, o iš tikrųjų kariniuose daliniuose buvo mažiau karių: 550 husarų (82 proc. numatytų etatų), 1930 petyhorų (77,5 proc.), 1660 lengvosios kavalerijos karių (75,7 proc.), 2933 dragūnai (55,3 proc.), 2726 péstininkai (51,3 proc.), 360 vengrų péstininkų ( 85,7 proc). Taigi, „popieriuje“ nurodyta maždaug 16300 etatų, o mūšio lauke buvo šiek tiek daugiau kaip 10000 karių $^{57}$. Šie duomenys iš esmès atitinka L. Pociejaus korespondencijoje pateikiamus kariuomenès $1712 \mathrm{~m}$. skaičius.

Artilerija buvo viena iš nedaugelio Lietuvos kariuomenès ginklo rūšių, kurios būklè $1712 \mathrm{~m}$. pagerèjo, nes $1711 \mathrm{~m}$. iš Rusijos buvo atsiimta dalis patrankų, išvežtų iš Lietuvos teritorijos iki $1709 \mathrm{~m}$. Artilerija buvo ruošiama $1712 \mathrm{~m}$. kampanijai: įsakyta surinkti reikiamus amatininkus, pagaminti įrenginius patrankoms transportuoti, paruošti kitus artilerijos reikmenis. L. Pociejus stengèsi artilerijos paruošimui panaudoti Neuburgų ir Sapiegų dvarų resursus. Netgi buvo norima kariuomenės reikmèms konfiskuoti visus Bychovo bažnyčių varpus, bet Vilniaus vaivada K. J. Sa-

\footnotetext{
54 L. Pociejus K. S. Radvilai, 1712 m. liepos 12-15 d. laiškai, AGAD, AR V, b. 11913.

55 Issiveržus į Lietuvą švedų partizanams, L. Pociejus A. Sieniavskio paprašė grąžinti ị pagalbą pasiųstas vèliavas, tiesa, istoriniuose šaltiniuose nèra žinių, ar jos suspejjo atvykti iki karinès kampanijos pabaigos. Žr.: L. Pociejus A. Sieniavskiui, 1712 m. liepos 12 d., BCzar, b. 5916 , nr. 30069 .

56 L. Pociejaus atsišaukimas, 1712 m. liepos 3 d., LVIA, SA, b. 14508, 1. 676-677.

57 Lietuvos kariuomenès sudètis (komputas), be datos, Vilniaus universiteto biblioteka, f. 4, b. (A157)-11403a.
} 
piega kategoriškai tam pasipriešino ${ }^{58}$.

Lietuvos kariuomenè 1711-1712 m. žiemą buvo išdèstyta taip: lengvosios kavalerijos vèliavos stovėjo pasienyje su Kunigaikštiškąja Prūsija, nuo sienos su Palenke iki pat Palangos, svetimšalių autoramento pėstininkų daliniai - Lietuvos Brastoje, Gardine ir Naugarduke, o svetimšalių autoramento kavalerija ir tautinio autoramento kavalerija - netoli Lenkijos sienos, kad prireikus greitai galètų ateiti ị pagalbą Lenkijos kariuomenei, jeigu švedai pultų iš Pamario arba kiltų grèsmè iš Benderų ${ }^{59} .1712 \mathrm{~m}$. gegužès mèn. Lietuvos kariuomenès sutelkimo vietos buvo Lietuvos Brasta (svetimšalių autoramento) ir Želva (tautinio autoramento), pusiaukelèje tarp Volkovysko ir Slonimo. Birželio viduryje daliniams prie Želvos buvo duotas įsakymas artèti link svetimšalių autoramento dalinių ${ }^{60}$.

Gegužès pabaigoje visi keturi Lenkijos ir Lietuvos etmonai susitiko netoli Liublino, kur turejjo būti suderinti karinès kampanijos prieš švedų partizanus veiksmai ${ }^{61}$. J. Grudzinskio ịsiveržimas visus nustebino. Lietuvos didysis etmonas buvo priverstas gegužès pabaigoje pasiųsti 30 Lietuvos kariuomenès kavalerijos vèliavų ì pagalbą Lenkijos didžiajam etmonui A. Sieniavskiui. Nors kavalerijos vẻliavos, kaip pažymèjo pats etmonas, ir nevisiškai buvo aprūpintos, bet morališkai pasirengusios kautis $^{62}$.

Istoriniai šaltiniai rodo, kad $1712 \mathrm{~m}$. birželio pradžioje J. K. Sapiega buvo Kunigaikštiškojoje Prūsijoje, Elko mieste, iš kur jam pavaldūs daliniai to mėnesio pabaigoje ịsiveržè i Lietuvą ${ }^{63}$. Galima numanyti, kad ryžtis naujam puolimui ji paskatino J. Grudzinskio įsiveržimas, o J. K. Sa-

58 L. Pociejus Stanislovui Niezabitovskiui (Stanisław Niezabitowski), 1712 m. vasario 1 d., AGAD, AR V, b. 11913; K. J. Sapiega karininkui Berlinkurtui (Berlincourt) Bychove, 1711 m. spalio 19 d., LMAVB, f. 139, b. 4004/2.

59 L. Pociejus J. Šembekui, 1711 m. gruodžio 31 d., BCzar, b. 461, nr. 148.

60 M. Ancuta K. S. Radvilai, 1712 m. gegužès 28 d., AGAD, AR V, b, 126; L. Pociejus A. Sieniavskiui, 1712 m. birželio 22 d., BCzar, b. 5916, nr. 30065.

61 Stanislovas Chomentovskis (Stanisław Chomętowski) Jonui Jurgiui Pšebendovskiui (Jan Jerzy Przebendowski), 1712 m. birželio 1 d., AGAD, AR V, b. 2115; L. Pociejus K. S. Radvilai, 1712 m. gegužès 13-21 d. laiškai, $A G A D$, AR V, b. 11913.

62 L. Pociejus J. Šembekui, 1712 m. gegužès 27 d., BC 462, nr. 76; L. Pociejus A. Sieniavskiui, 1712 m. birželio 10-22 d. laiškai, BCzar, b. 5916, nr. 30062-30065.

63 L. Pociejus J. Šembekui, 1712 m. birželio 8 d., BCzar, b. 462, nr. 106. 
piega vykdè Benderuose parengtą kampanijos planą ${ }^{64}$.

L. Pociejus buvo ịsitikinęs, kad J. K. Sapiegos daliniai žygiuos ị Didžiąą Lenkiją J. Grudzinskio link ${ }^{65}$. Visgi jie netikètai pasuko ị rytus, Gardino link. Nèra istorinių dokumentų, kurie paaiškintų tokị jų elgesį, bet greičiausiai buvo gauta žinių, kad J. Grudzinskio pasiekti nepavyks. Birželio pabaigoje J. Grudzinskis jau buvo supamas iš visų pusių Lenkijos ir Rusijos kariuomenių dalinių. Itvairiais duomenimis, J. K. Sapiegai pavaldžių karių buvo nuo 500 iki 3000. Iš pradžių partizanams sekèsi: prie jų prisijungè dezertyravusi Lietuvos kariuomenès petyhorų vẻliava, kita kavalerijos vèliava buvo užpulta ir pasidavè be mūšio ${ }^{66}$. Prie Zabludavo partizanai pasuko ị šiaurès rytus, link Gardino, pakeliui prie Odelsko užpuolę dar vieną ten stovinčią Lietuvos kariuomenès petyhorų vèliavą. Gardine buvo nedidelè Rusijos kariuomenès igula, maždaug 120 karių, kurie prižiūrèjo maisto ir pašarų rinkimą Rusijos kariuomenės grupėms, visą vasarą žygiuojančioms iš Smolensko ị Švedijos Pamarị padėti Saksonijos ir Danijos kariuomenėms. Šis rusų pėstininkų dalinys su partizanais ị atvirą mūšį nestojo ir užsidarẻ Gardino pilyje.

Gavęs žinių apie partizanų veiksmus, L. Pociejus su Lietuvos kariuomene pajudejo link Gardino, norèdamas užtverti jiems atsitraukimo kelią link Kunigaikštiškosios Prūsijos sienos. Nors pirmieji veiksmai buvo sẻkmingi, moralinè švedų partizanų būklè nebuvo gera, o prie to dar prisidejo ir žinios apie J. Grudzinskio pajègų išsklaidymą. Partizanų gretose atsirado dezertyrų ${ }^{67}$.

64 Savo atsiminimuose Kristupas Zaviša (Krzysztof Zawisza) teigia, kad J. K. Sapiega, gavęs žinių apie J. Grudzinskio įsiveržimą, su 500 raitelių siekė prisijungti prie jo. Žr.: $P a$ miętniki Krzysztofa Zawiszy, wojewody mińskiego (1666-1721): wydane z oryginalnego rękopismu i opatrzone przypiskami, red. J. Bartoszewicz, Warszawa, 1862, s. 300-301. M. Vagneris, teigdamas, kad J. K. Sapiega birželio pabaigoje buvo prie Gniezno, suklydo. Žr.: Wagner M. Zagon Kawaleryjski Jana Grudzińskiego w 1712 roku, s. 217.

65 L. Pociejus A. Sieniavskiui, 1712 m. birželio 15 d., BCzar, b. 5916, nr. 30063.

${ }^{66}$ K. Zaviša savo atsiminimuose nurodo, kad J. K. Sapiega turèjo 500 vyrų, o Vilniaus vyskupystès sufraganas Motiejus Ancuta - kad 3000. Tikėtina, kad K. Zavišos, buvusio švedų šalininko Lietuvoje, pateiktas skaičius yra tikslesnis. Be to, sunku įsivaizduoti, kaip 3000 vyrų galèjo būti užverbuoti 1711-1712 m. žiemą ir išsilaikyti Kunigaikštiškojoje Prūsijoje, žinant, kad švedų partizanams nuolatos trūko pinigų. Žr.: Pamiętniki Krzysztofa Zawiszy, s. 300-301. M. Ancuta K. S. Radvilai, 1712 m. liepos 2 d., AGAD, AR V, b. 126. 67 L. Pociejus K. S. Radvilai, 1712 m. liepos 12-15 d. laiškai, AGAD, AR V, b, 11913. 


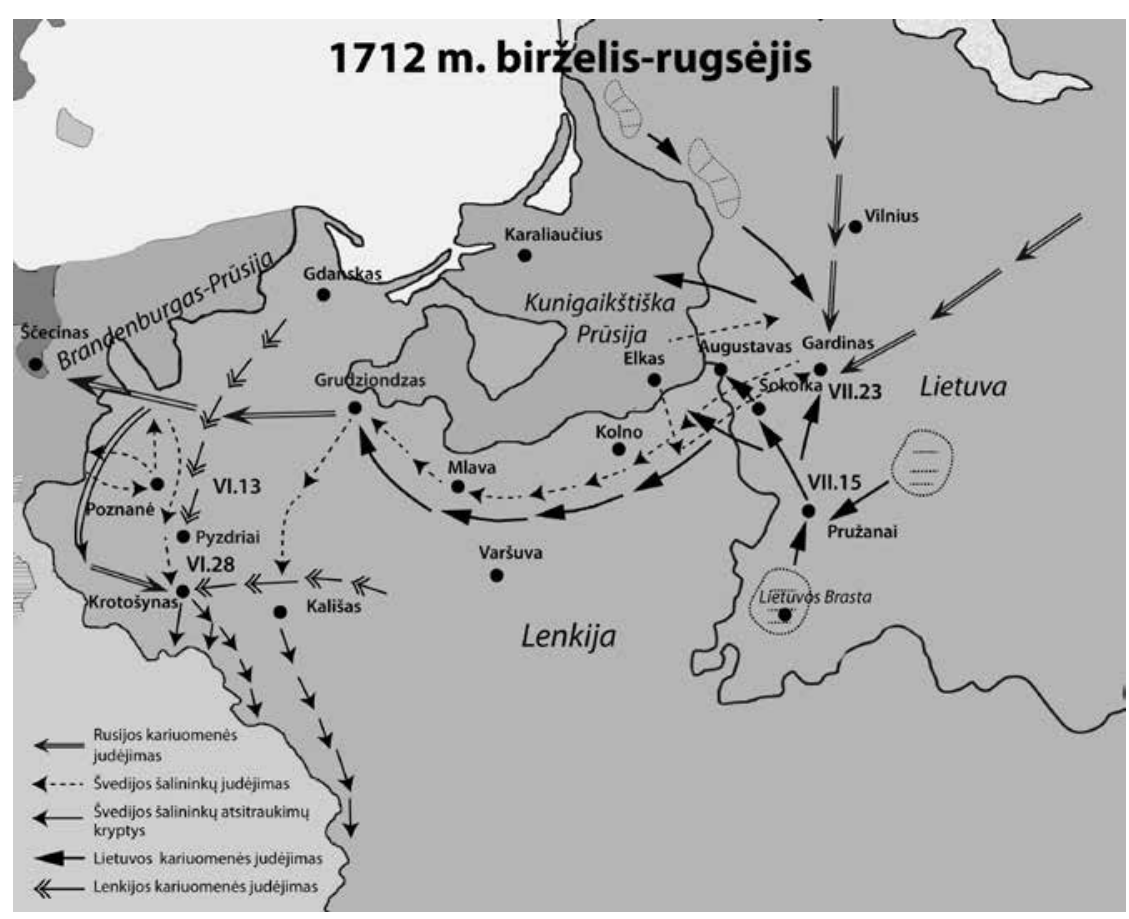

2 pav. Kariuomenių judejjimo kryptys 1712 m. birželio - rugsèjo mèn.

Tebevykstant karo veiksmams buvo mąstoma ir apie diplomatines priemones. Iš istorinių šaltinių užuominų galima numanyti, kad pats J. K. Sapiega nedalyvavo ịsiveržime ị Lietuvos teritoriją, o liko Kunigaikštiškojoje Prūsijoje, vèliau persikèle ị Kolno miestą Palenkès vaivadijoje. Partizanų daliniams vadovavo karininkas M. Chmara. Tai galima sieti su derybomis, mat birželio pabaigoje pas L. Pociejų atvyko Lietuvos lauko raštininkas M. J. Sapiega, kuris su Lietuvos didžiuoju etmonu derèjosi dèl J. K. Sapiegos perėjimo ị Augusto II pusę. Be to, valdovas buvo atsiuntęs L. Pociejui savo pasirašytas amnestijas J. K. Sapiegai ir kitiems švedų partizanams. L. Pociejus, ko gero, nebuvo susitaikymo šalininkas, be to, nebuvo ir laisvų urèdų, kuriais J. K. Sapiegą būtų galima patraukti ¡ Augusto II pusę. Kaip minèta, pats Lietuvos didysis etmonas savo laiške rašè, kad J. K. Sapiegos pretenzijos didelès, o pagrindas joms niekinis. Karine persvara buvo L. Pociejaus pusèje, todèl jis nusprende išsiųsti am- 
nestijas J. K. Sapiegai per Lietuvos Brastos seniūną Joną Frederyką Sapiegą (Jan Fryderyk Sapieha), o pats žygiuoti prieš švedų partizanus su visa Lietuvos kariuomene, nes „jų kas kartą daugejja, ir šètonas težino, iš kur jų tiek atsiranda"68.

Liepos viduryje L. Pociejus su kariuomene, kurios abu autoramentai jau buvo susijungę, trauke šiaurès vakarų kryptimi. Liepos $15 \mathrm{~d}$. jis buvo prie Pružanų (Пружаны), liepos 17 d. - prie Novy dvoro (Новы Двор), iš kur buvo pasiųstos lengvosios kavalerijos vèliavos link Gardino gaudyti partizanų. Pats L. Pociejus su pagrindinèmis pajėgomis planavo žygiuoti link Augustavo ir atkirsti partizanus nuo Kunigaikštiškosios Prūsijos. Liepos 19 d. buvo pasiektas Svisločius (Свислочь). Vidutinis kariuomenės žygiavimo greitis buvo $19-20 \mathrm{~km}$ per dieną ${ }^{69}$. Visgi partizanų kavalerijos daliniai buvo greitesni, ir jau liepos 20 d. L. Pociejus gavo žinių, kad jie nuo Gardino pasitraukẻ link Kunigaikštiškosios Prūsijos sienos greičiausiai dèl to, kad ị Gardiną atžygiavo naujų Rusijos kariuomenès dalinių, maždaug 7000 karių. Iš Svisločiaus buvo pasiųstos dar keturios lengvosios kavalerijos vèliavos viliantis, kad bent dali partizanų pavyks pagauti, iki jie pasitrauks ị Kunigaikštiškąją Prūsiją. Vèliavos pasieké Augustavą, bet partizanų ten nebuvo nẻ kvapo. Jie buvo pasitraukę link Kolno, kur tuo metu buvo J. K. Sapiega. Liepos 21 ar 22 d. prie Bebro (Biebrza) upès Lietuvos kariuomenès vẻliavoms pavyko pavyti partizanus ir paimti kelis $\mathfrak{i}$ nelaisvę. Vèliau partizanai kontratakavo. Lietuvos kariuomenès kavalerijos kariai tuo metu ilsejjosi, nusèdę nuo žirgų, ir partizanų kontrataka jiems buvo netikèta. Po gerą pusdienị trukusio susišaudymo 7 Lietuvos kariuomenès kariai žuvo. Abi pusès paèmẻ belaisvių. Nežinoma, kiek žuvo partizanų. Sužeistuosius jie išsigabeno su savimi ${ }^{70}$.

Po mūšio partizanai persikèle per Bebro upę ir sunaikino tam panaudotas valtis, o paskui pasitraukè link Kolno, kur jų laukè J. K. Sapiega. Ten buvo nuspręsta trauktis pietvakarių kryptimi link Vyslos, mat patraukus

\footnotetext{
68 L. Pociejus A. Sieniavskiui, 1712 m. liepos 4 d. ir 17 d. laiškai, BCzar, b. 5916, nr. 30066, 30071.

69 L. Pociejus K. S. Radvilai, 1712 m. liepos 15 d., AGAD ARV 11913; L. Pociejus A. Sieniavskiui, 1712 m. liepos 17-19 d. laiškai, BCzar, b. 5916 nr. 30071-30072.

70 L. Pociejus K. S. Radvilai, 1712 m. liepos 20-23 d. laiškai, AGAD, AR V, b. 11913;

L. Pociejus A. Sieniavskiui, 1712 m. liepos 24 d., BCzar, b. 5916, nr. 30073.
} 
link Prūsijos būtų tekę susidurti su pagrindine Lietuvos kariuomene. L. Pociejaus vertinimu, tuo metu J. K. Sapiega galejo turèti kelis šimtus raitarų ir kelis šimtus tautinio autoramento kavalerijos karių. L. Pociejus įsake Lietuvos kariuomenès kavalerijos vèliavoms persekioti priešą iki Vyslos, taip pat buvo nusiųsti laiškai A. Sieniavskiui, kad jis iš kitos Vyslos pusės prieš partizanus pasiųstų Lenkijos kariuomenès dalinius ${ }^{71}$. Liepos $28 \mathrm{~d}$. J. K. Sapiega buvo prie Mlavos, kur vienai dienai sustojo pailsèti, ir link Varšuvos ir Plocko pasiuntè žvalgus, kurie turèjo rasti saugią vietą persikelti per Vyslą. Tuo tarpu Lietuvos kariuomenès pagrindinès pajègos pajudèjo ị pietus ir rugpjūčio $1 \mathrm{~d}$. pasieke Tikociną ${ }^{72}$. Tuomet persekiojimas ir karo veiksmai buvo sustabdyti maždaug savaitei - abi pusès užèmè savo pozicijas ir laukè. Galbūt tai galima paaiškinti tuo, kad J. K. Sapiega buvo populiarus tarp Plocko vaivadijos bajoruc ir kad pagrindine Lietuvos kariuomene priartejo prie Lenkijos karalystès sienos arba ją kirto (nèra istorinių šaltinių, kurie rodytų, kurie Lietuvos kariuomenès daliniai pasiekè Tikociną, jau priklausantị Lenkijai). Greičiausiai ị Palenkès ir Mazovijos vaivadijas, priklausančias Lenkijai, buvo įžengusi ne pagrindiné Lietuvos kariuomené, o tik kai kurie jos daliniai ${ }^{73}$.

L. Pociejus labai aktyviai kovojo su partizanais. Žinoma, J. K. Sapiega buvo jo asmeninis priešas ir pagrindinis konkurentas, kurị reikejo ịveikti, tačiau taip pat verta atkreipti dèmesị i Rusijos poziciją $1712 \mathrm{~m}$. viduryje. L. Pociejus žinojo, kad jeigu švedų partizanai nebus sutramdyti, Rusijos kariuomenè pasiliks žiemoti dešiniakrantèje Ukrainoje ir Lietuvoje, kuri visus $1712 \mathrm{~m}$. kentejjo nuo Rusijos kariuomenès dalinių, žygiuojančių i Švedijos Pamarị, o L. Pociejus turèjo nuolatos klausyti bajorijos skundų ir prašymų apginti ją nuo Rusijos kariuomenès kontribucijų ${ }^{74}$. Iš tikrųjų rugpjūčio pradžioje Rusijos kariuomenès vadovybè išleido atsišaukimus, kuriuose įspèjo, kad, jeigu lenkų ir lietuvių bajorija jungsis prie švedų

71 L. Pociejus A. Sieniavskiui, 1712 m. liepos 29 d., BCzar, b. 5916, nr. 30074; L. Pociejus K. S. Radvilai, 1712 m. liepos 29 d., AGAD, AR V, b. 11913.

72 L. Pociejus K. S. Radvilai, 1712 rugpjūčio 1 d., $A G A D$, AR V, b. 11913; L. Pociejus A. Sieniavskiui, 1712 m. rugpjūčio 1 d., BCzar, b. 5916, nr. 30076.

73 L. Pociejus A. Sieniavskiui, 1712 m. rugpjūčio 6 d., BCzar, b. 5916, nr. 30078; L. Pociejus K. S. Radvilai, 1712 m. rugpjūčio 6-9 d. laiškai, $A G A D$, AR V, b. 11913.

74 Borisas Šeremetjevas (Борис Шереметев) Petrui I, 1712 m. liepos 11 d., Шереметев Письма к государю императору Петру Великому, Москва, 1779, т. 3, с. 158-160. 
partizanų, Rusijos kariuomene bus priversta šị maištą numalšinti ${ }^{75}$.

Rugpjūčio viduryje L. Pociejus pasiunte kavalerijos dalinius, vadovaujamus savo pusbrolio Trakų vaivados Kazimiero Oginskio (Kazimierz Ogiński), prieš J. K. Sapiegą. K. Oginskio daliniai vijosi J. K. Sapiegą ir jo karius iki pat Grudziodzo (Grudziądz), kur J. K. Sapiega norèjo persikelti per Vyslą. Situacija buvo J. K. Sapiegai nepalanki, nes brastą saugojo Lenkijos kariuomenés patruliai. J. K. Sapiega prijojo prie Lenkų kariuomenès dalinio ir karininkui pasakè, kad vejasi J. K. Sapiegą ir jam skubiai reikia persikelti per Vyslą. Apgaulè pavyko, ir Lenkų kariuomenès dalinys leido J. K. Sapiegai ir jo kariams persikelti. Po kelių valandų atvykęs K. Oginskis suprato, kad pavèlavo. Persikèlęs per Vyslą, J. K. Sapiega užpuolè ir išžudè netoliese buvusią Rusijos kariuomenès karių kuopą. Galbūt suprasdamas, jog jo karių grupé yra per didelè, kad prasmuktų toliau nepastebèta (netoliese buvo 1000 karių Rusijos kariuomenès dalinys), J. K. Sapiega atliko taktinị manevrą: svetimšalių autoramento kariams įsake apsisukti ir grị̌ti ị Kunigaikštišką̧ą Prūsiją, o pats patraukè ị pietus, link Kališo, kur ịvyko nedidelis mūšis su Lenkijos kariuomenès daliniu. Svetimšaliu autoramento raiteliai, pastebėti K. Oginskio žvalgų, buvo persekiojami iki pat Kunigaikštiškosios Prūsijos sienos. Partizanų nepavyko pagauti - jie, kirtę sieną, išsiskirstė mažomis grupelèmis Prūsijos gilumoje ${ }^{76}$. Galbūt partizanai buvo vikresni už Lietuvos kariuomenès kavaleriją ar K. Oginskio daliniai, gaudantys J. K. Sapiegą, labiau domėjosi plèšikavimu ir savavališku kontribucijų rinkimu negu karo veiksmais - istoriniai šaltiniai pateikia tokius skundus ${ }^{77}$.

J. K. Sapiegą iki Kališo galëjo lydèti nuo keliasdešimties iki kelių šimtų raitelių ${ }^{78}$. Iš ten jis judèjo Krokuvos kryptimi. Netoli Krokuvos rugsejo pradžioje jo pajègos buvo dar kartą išsklaidytos Lenkijos kariuomenès

\footnotetext{
75 B. Šeremetjevo atsišaukimas, $1712 \mathrm{~m}$. rugpjūčio $3 \mathrm{~d}$. (senasis spaudinys).

76 L. Pociejus A. Sieniavskiui, 1712 m. rugpjūčio 24 d., BCzar, b. 5916, nr. 30079; L. Pociejus K. S. Radvilai, 1712 m. rugpjūčio 24 d, $A G A D$, AR V, b. 11913.

77 J. Z. Rybinskis A. Sieniavskiui, 1712 m. rugpjūčio 29 d., BCzar, b. 5937, nr. 35508.

78 J. Z. Rybinskio duomenys, kad J. K. Sapiega turèjo daugiau kaip kelis tūkstančius vyrų, yra netikslūs. J. Z. Rybinskis buvo toli nuo karo veiksmų teatro (rugpjūčio pabaigoje Liublino apylinkėse) ir menkai informuotas. Tai aiškeja iš to, kad J. Rybinskis rašè, jog J. K. Sapiega rugpjūčio pabaigoje pasitraukè atgal ị Kunigaikštiškąją Prūsiją. Žr.: J. Z. Rybinskis A. Sieniavskiui, 1712 m. rugpjūčio 29 d., BCzar, b. 5937, nr. 35508.
} 
dalinių. Vèliau su dar mažesne palyda J. K. Sapiega tęsè savo kelionę Vienos link. Jo tikslas buvo pasiekti Benderus ir Karoli XII. Yra žinoma, kad J. K. Sapiega Vieną tikrai pasiekè $1712 \mathrm{~m}$. rugsèjo 29 d. ir iš ten inkognito, prisidengęs Švedijos karininko pavarde, tęsè savo kelionę Benderų link. Korespondenciją ir komunikaciją su likusiais šalininkais Kunigaikštiškojoje Prūsijoje J. K. Sapiega galvojo palaikyti per Vroclavą, nes ten paliko vieną savo karininkų, kuris turèjo persiųsti laiškus ị Karaliaučių. Pakeliui J. K. Sapiega parašè laišką Merkinès seniūnui A. K. Sapiegai, kuris vis dar buvo Kunigaikštiškojoje Prūsijoje. J. K. Sapiega A. K. Sapiegai ìsake nepaleisti tarnyboje esančių žmonių ir pažadejjo greitai pats sugrižzti. M. Chmara ir visi jam pavaldūs žmonès turèjo paklusti A. K. Sapiegos valiai $^{79}$. Pasitraukus J. K. Sapiegai ir partizanų likučiams grịžus ị Kunigaikštišką̧ą Prūsiją, Lietuvos kariuomenè spalio viduryje buvo paleista ị žiemojimo vietas. Tiesa, iš atsargumo žiemojimo vietos buvo parinktos netoli Lenkijos ir Kunigaikštiškosios Prūsijos sienų ${ }^{80}$.

Kaip minèta, 1711 m. partizanams Kunigaikštiškojoje Prūsijoje trūko ir pinigų, ir kitų būtinų, kad išgyventų, dalykų, nekalbant jau apie karinius reikmenis ir ginklus. Nežinoma, kada J. K. Sapiegos laiškai, kuriuose buvo ịsakyta nepaleisti žmonių iš tarnybos, pasiekẻ Kunigaikštiškająa Prūsiją, bet po nesèkmingo $1712 \mathrm{~m}$. žygio ten esantys partizanų karininkai nusprendè visus partizanus, kurie neturi žirgų ir tinkamos ginkluotès, paleisti iš tarnybos, o tuos, kurie neturi žirgo, bet turi ginklų, taip pat paleisti, bet prieš tai atimti jų ginkluotę. Rugpjūčio pabaigoje L. Pociejus dar pakursté ugnị, grasindamas ịsiveržti ị Kunigaikštišką̧ą Prūsiją su 10 tūkstančuu Lietuvos kariuomenès karių ir pats išgaudyti visus partizanus, jeigu Brandenburgo-Prūsijos vadovybè nesiims kokių nors priemonių jiems sutramdyti. Partizanai dar nebuvo išvyti, bet jiems jau buvo įsakyta pasitraukti $\mathfrak{i}$ krašto gilumą ir laikytis mažomis grupelèmis, kad niekam nekristų i akis. Prie katastrofiškos partizanų padèties prisidejo ir Vilniaus vaivada K. J. Sapiega, kuris paragino Brandenburgo-Prūsijos valdžios organus išvyti švedų šalininkus iš savo teritorijos. K. J. Sapiega buvo parašęes laišką ir J. K. Sapiegai, siūlydamas jam nedaryti kvailysčių ir susitaikyti

\footnotetext{
79 J. K. Sapiega A. K. Sapiegai, 1712 m. rugsèjo 15 ir 29 d. laiškai, $L M A V B$, f. 139, b. 4000/2.

80 L. Pociejus A. Sieniavskiui, 1712 m. spalio 13 d. ir 18 d. laiškai, BCzar, b. 5916, nr. 30083-30084.
} 
su Augustu II. Atsidūrę beviltiškoje padètyje, švedų šalininkai bandè siūlytis tarnauti Prūsijos karaliui, t. y. būti priimti ị jo kariuomenę. Bet atsakymas, kurị išgirdo J. P. Buda, buvo netikètas. Jam buvo paaiškinta, kad J. K. Sapiegai paklūstantys žmonès padarẻ tiek daug eibių Lenkijoje ir Lietuvoje savo teisètam karaliui Augustui II, kad Prūsijos karalius tiesiog negalètų jais pasitikèti ${ }^{81} .1712$ m. spalio mèn. Augustas II paragino L. Pociejų ir K. S. Radvilą imtis aktyvesnių veiksmų, kad švedų šalininkai būtų patraukti į valdovo teismą už tèvynès išdavimą ${ }^{82}$. Norèdami išgaudyti likusius partizanus Kunigaikštiškojoje Prūsijoje, Lenkijos kariuomenès regimentorius J. Z. Rybinskis ir Lietuvos didysis etmonas L. Pociejus sutare prie sienos išdèstyti sargybos postus. Nuo Grudziodzo iki Tikocino sieną turejo saugoti Lenkijos kariuomenè, o nuo Tikocino iki Palangos - Lietuvos kariuomenè. 1712 m. rugsèjo pabaigoje Prūsijoje dar galejo slèptis maždaug 200 Švedijos karaliui ir Stanislovui Leščinskiui ištikimų partizanų $^{83}$. Švedijos šalininkų stovyklos griūtị $1712 \mathrm{~m}$. pabaigoje ịprasmino slapta Rybnicos (Riebnitz) sutartis, sudaryta Augusto II ir Stanislovo Leščinskio (tiesa, Karolis XII atsisakè ją pripažinti), kuria pastarasis atsisakè savo teisių i Respublikos sostą.

Dauguma partizanų grịžo ị Lenkiją ir Lietuvą $1712 \mathrm{~m}$. pabaigoje ir 1713 m. pradžioje. Dalis jų, greičiausiai eiliniai kariai, buvo pagauti Lietuvos kariuomenès sargybos postuose pasienyje. Yra žinoma, kad jie buvo areštuoti, tačiau nèra duomenų apie tolesnị jų likimą ${ }^{84} .1713$ m. pradžioje Augustas II pasirašè nemažai pakartotinių amnestijų švedų šalininkams: pulkininkui M. Chmarai, Merkinès seniūnui A. K. Sapiegai, J. P. Budai, J. K. Sapiegai ir kitiems. Pagal amnestijos sąlygas, jie per 12 savaičių

81 J. P. Buda karininkui, 1712 m. rugsejjo 7 d., $L M A V B$, f. 139, b. 432; J. P. Buda A. K. Sapiegai, 1712 m. rugsèjo 1- spalio 4 d. laiškai, $L M A V B$, f. 139, b. 432; L. Pociejus A. Sieniavskiui, 1712 m. rugpjūčio 24 d., BCzar, b. 5916, nr. 30079; Liudvika Opalinska (Ludwika Opalińska) A. K. Sapiegai, 1712 m. gruodžio 19 d., LMAVB, f. 139, b. 4000/2.

${ }^{82}$ J. Šembekas K. S. Radvilai, 1712 m. spalio 16 d., AGAD, AR V, b. 15699; Augustas II K. S. Radvilai, 1712 m. rugsejjo 4 d., $A G A D$, AR III, b. 21. Tiesa, nèra duomenų, kad bent viena byla buvo pradèta.

${ }^{83}$ J. Z. Rybinskis A. Sieniavskiui, 1712 m. rugsèjo 7 ir 23 d. laiškai, BCzar, b. 5937, nr. 35509, 35512.

84 L. Pociejus K. S. Radvilai, 1712 m. lapkričio 23 d., AGAD, AR V, b. 11913; L. Pociejus A. Sieniavskiui, 1712 m. lapkričio 16 d., BCzar, b. 5916, nr. 30086. 
turejo grižti ị Respubliką ir ịvykdyti Sandomiro konfederacijos priesaikos reikalavimus. Tai padariusiems asmenims buvo garantuojama asmeninè ir turto neliečiamybe $\dot{e}^{85}$. J. K. Sapiega grịžo $1713 \mathrm{~m}$. gegužę ${ }^{86}$.

\section{IŠVADOS}

Nors J. Grudzinskio žygis truko beveik du mėnesius, jam pavyko įsiskverbti gana giliai $\mathfrak{i}$ Lenkijos teritoriją nesutikus iš esmès jokio pasipriešinimo, o J. K. Sapiegos pajègos iš karto susidūrè su aktyvia Lietuvos kariuomene. Taip ìvyko dèl to, kad J. Grudzinskio žygis buvo gana netiketas, o J. K. Sapiegos daliniai puolè tada, kai Lietuvos kariuomenè buvo pasiruošusi gynybos veiksmams. $1711 \mathrm{~m}$. nuolatiniai partizanų puldinëjimai iš Kunigaikštiškosios Prūsijos verte Lietuvos kariuomenès vadovybę tikèti, kad ir $1712 \mathrm{~m}$. bus vykdomi panašǔs puolimai. Nemažą vaidmenį suvaidino tai, kad Vakarų Lietuvoje J. K. Sapiegos dalinių puolimo metu buvo gausios Rusijos kariuomenès pajègos, kurios, nors ir nedalyvavo veiksmuose prieš partizanus, gerokai varžè jų veiksmų laisvę.

Su švedų partizanais buvo susidorota ganètinai lengvai. Kiek sunkiau ejosi Lenkijoje, tačiau tai suprantama, žinant objektyvias aplinkybes: teritorija, ị kurią galèjo ịsiveržti partizanai, buvo kur kas didesnè (Lietuvoje reikejo tik saugoti sieną su Prūsija), be to, J. Grudzinskio pajègos buvo kur kas gausesnès už J. K. Sapiegos. Svarbu tai, kad Lietuvos ir Lenkijos kariuomenių veiksmus buvo siekiama koordinuoti.

Nesèkminga $1712 \mathrm{~m}$. Švedijos karinè kampanija, turkų nenoras aktyviais karo veiksmais remti Karolio XII, nesèkminga Švedijos Pamario

\footnotetext{
${ }^{85}$ Amnestija M. S. Višnioveckiui, J. Potockiui, 1713 m. kovo 24 d. AGAD, Metryka Koronna, b. S-18, s. 36-37; Amnestija M. Chmarai ir visiems Prūsijoje esantiems jam paklūstantiems kariams, amnestija A. K. Sapiegai, amnestija J. P. Budai, amnestija J. K. Sapiegai, 1713 m. kovo 24 d., LVIA, LM, b. 159, 1. 161-164, 170-171; Stefanas Humieckis (Stefan Humiecki) A. Sieniavskiui, 1713 m. balandžio 26 d., BCzar, b. 5834, nr. 15107.

${ }^{86}$ Prie J. K. Sapiegos apsisprendimo grịžti ị Respubliką daug prisidejo ir tai, kad Karolis XII Benderuose ji sutiko nenoriai. Švedijos karaliaus favoritas buvo M. S. Višnioveckis, todẻl buvo aišku, kad ir sunkiai ịsivaizduojamo Stanislovo Leščinskio sugrąžinimo ị Respublikos sostą atveju Lietuvos didžiuoju etmonu būtų tapęs M. S. Višnioveckis, o ne J. K. Sapiega. Žr.: Feldman J., Polska a sprawa wschodnia 1709-1714, Kraków, 1926, s. 105.
} 
gynyba nuo sąungininkų, Švedijos karinis nusilpimas, jos kariuomenès desanto vèlyvas išsilaipinimas Riugeno saloje, aktyvi Lenkijos ir Lietuvos pareigūnų kova su partizanais ir visuotinis Respublikos bajorijos noras užbaigti metų metus trunkančią politinę suirutę lèmé Švedijos šalininkų pralaimejjimą.

Tai buvo paskutiniai kovos su bendru priešu - Švedija ar jos šalininkais - veiksmai Lietuvos Didžiosios Kunigaikštystès ir Lenkijos karalystès teritorijoje Didžiojo Šiaurès karo metais. Nesèkminga 1712 m. kampanija galutinai sužlugdè Švedijos karaliaus Karolio XII lenkiškosios politikos planus - pavergti kraštą ir priversti paklusti Stanislovui Leščinskiui.

\section{ŠALTINIŲ IR LITERATŪROS SĄRAŠAS}

Feldman J. Polska a sprawa wschodnia 1709-1714. Kraków, 1926.

Forycki M. Stanisław Leszczyński. Poznań, 2016.

Gierowski J. A. Między saskim absolutyzmem a złotą wolnością. Z dziejów wewnętrznych Rzeczypospolitej w latach 1712-1715. Wrocław, 1953.

Jarochowski K. Wycieczka Grudzińśkiego, starosty Rawskiego, do Polski w roku 1712. Opowiadania i studia historyczne, t. 2. Poznań, 1863, s. 317-385.

Rakutis V. Liudvikas Konstantinas Pociejus (1709-1730). Lietuvos krašto apsaugos ministrai ir kariuomenés vadai, I tomas LDK didieji etmonai ir sukilimu vadai. Vilnius-Kaunas, 2008.

Šapoka M. Lietuvos Didžiosios Kunigaikštystès kariuomenè 1710$1711 \mathrm{~m}$. Lietuvos istorijos metraštis, 2017 metai, 1 (2017), p. 23-48.

Šapoka M. Warfare, Loyalty and Rebellion: The Grand Duchy of Lithuania and the Great Northern War, 1709-17. London, New York, NY, 2018.

Wagner M. Zagon Kawaleryjski Jana Grudzińskiego w 1712 roku. Wojny pólnocne w XVI-XVIII wieku, red. B. Dybaś. Toruń, 2007, s. 209223.

Wimmer J. Wojsko Rzeczypospolitej w dobie wojny północnej (17001717). Warszawa, 1956. 


\section{Publikuoti šaltiniai}

B. Šeremetjevo atsišaukimas, $1712 \mathrm{~m}$. rugpjūčio $3 \mathrm{~d}$. [be v.]

Pamiętniki do panowania Augusta II, napisane przez niewiadomego autora (podobno Erazma Otwinowskiego), wyd. E. Raczyński. Poznań, 1838.

Pamiętniki Krzysztofa Zawiszy, wojewody mińskiego (1666-1721): wydane $\mathrm{z}$ oryginalnego rękopismu i opatrzone przypiskami, red. J. Bartoszewicz. Warszawa, 1862.

Summaryusz Calculacyey ex perceptis et distributis Importancyi dwuletney z prowentow Rzeczypospolitey WXL mianowicie cła nowopodwyższonego, donativum Kupieckiego, y monopolium tabacznego [be v. ir d.].

Письма и бумаги Императора Петра Великого, т. 11, вып. 2. Москва, 1964.

Шереметев - Письма к государю императору Петру Великому. Москва, 1779, т. 3.

\section{Archyviniai šaltiniai}

Archiwum Główne Akt Dawnych (AGAD)

Archiwum Radziwłłów $(A R)$

II, b. 2236

III, b. 21

IV, Nr. 17

V, b. 126, 2115, 2956, 4204, 11536, 11913, 15699

Metryka Koronna:

b. S-18

Biblioteka Czartoryskich (BCzar):

b. $461,462,488,493,559,5791,5834,5915,5916,5928$, 5937, 5943

Lietuvos mokslų akademijos Vrublevskių biblioteka (LMAVB):

f. 139, b. $432,2328,4000 / 1,4000 / 2,4004 / 2,4064 / 1$

Lietuvos valstybès istorijos archyvas (LVIA):

Senieji aktai (SA), b. 56, 14508

Lietuvos metrika (mikrofilmai), b. 155, 159 
Polska Akademia Nauk Biblioteka Kórnicka

b. 412

The National Archives in Kew (TNA), State papers (SP), 88

b. 18,19

Vilniaus universiteto biblioteka (VUB)

f. 4 , b. (A157)-11403a

Iteikta $2018 \mathrm{~m}$. lapkričio $13 \mathrm{~d}$. 


\title{
LITHUANIAN ARMED FORCES' CAMPAIGN IN 1712 AND POTENTIAL FOR PRO-SWEDISH COUP IN THE GRAND DUCHY OF LITHUANIA
}

\author{
Dr. Mindaugas ŠAPOKA \\ Lithuanian Institute of History
}

The article analyzes the last campaign of the Great Northern War in the territory of the Grand Duchy of Lithuania. After the Battle of Poltava in 1709, part of the loyal officers of Stanislaus I (Lithuanian: Stanislovas Leščinskis), King of Poland and Grand Duke of Lithuania and protégé of Charles XII of Sweden, moved to the Duchy of Prussia that belonged to Brandenburg-Prussia. In the period of 1711-1712, they recruited military units and attacked Lithuanian territories to destabilize the situation and prepare the ground for a coup during which Stanislaus I would regain the Polish-Lithuanian throne. The attacks were led by Jonas Kazimieras Sapiega, former Grand Hetman of Lithuania appointed by Stanislaus I. Charles XII, Stanislaus I and their supporters' plan for the military campaign in 1712 was based on two main pillars. First, it was planned to direct cavalry units from the territory of the Ottoman Empire to the Kingdom of Poland. Having invaded the kingdom, they had to hold the attention of the Polish troops. At that time, the Swedish assault forces had to land on the Swedish seashore, defeat the joint forces of Saxony, Russia and Denmark and enter Poland. Concurrently, the units of the Ottoman Empire had to join the war and attack Russia and the Ukrainian territory on the right bank of the river Dnepr. Then, Jonas Kazimieras Sapiega and his Prussian units had to attack Lithuania. The plan failed because of the failed attacks on Poland and Lithuania. The troops led by Jonas Grudzinskis at the end of June 1712 were scattered by the Lithuanian and Polish armies. Likewise, the raid to Lithuania led by Jonas Kazimieras Sapiega in June-July 1712 also broke down as the army loyal to Augustus II the Strong was much bigger and better prepared for the attack. The late landing of the Swedish forces demoralized the units of Jonas Grudzinskis and Jonas Kazimieras Sapiega. 
The unsuccessful campaign, the Turks' unwillingness to actively support Charles XII with military actions, failed defence of the Swedish seashore from the allies, Sweden's weakened military power and late landing on Rügen Island, active fights among Poles, Lithuanians and Swedish supporters and common desire of the Polish-Lithuanian Commonwealth's nobility to finally end the political turmoil lasting for years led to the Swedish supporters' defeat. 